\title{
Comparison of different evaporation estimates over the African continent
}

\author{
P. Trambauer ${ }^{1}$, E. Dutra ${ }^{2}$, S. Maskey ${ }^{1}$, M. Werner ${ }^{1,3}$, F. Pappenberger ${ }^{2}$, L. P. H. van Beek ${ }^{4}$, and S. Uhlenbrook ${ }^{1,5}$ \\ ${ }^{1}$ UNESCO-IHE, Department of Water Science and Engineering, P.O. Box 3015, 2601 DA Delft, the Netherlands \\ ${ }^{2}$ ECMWF, Shinfield Park, RG2 9AX Reading, UK \\ ${ }^{3}$ Deltares, P.O. Box 177, 2600MH Delft, the Netherlands \\ ${ }^{4}$ Utrecht University, Dept. Physical Geography, Utrecht, the Netherlands \\ ${ }^{5}$ Delft University of Technology, Water Resources Section, P.O. Box 5048, 2600 GA Delft, the Netherlands
}

Correspondence to: P. Trambauer (p.trambauer@unesco-ihe.org)

Received: 3 June 2013 - Published in Hydrol. Earth Syst. Sci. Discuss.: 2 July 2013

Revised: 13 November 2013 - Accepted: 2 December 2013 - Published: 15 January 2014

\begin{abstract}
Evaporation is a key process in the water cycle with implications ranging, inter alia, from water management to weather forecast and climate change assessments. The estimation of continental evaporation fluxes is complex and typically relies on continental-scale hydrological models or land-surface models. However, it appears that most global or continental-scale hydrological models underestimate evaporative fluxes in some regions of Africa, and as a result overestimate stream flow. Other studies suggest that landsurface models may overestimate evaporative fluxes. In this study, we computed actual evaporation for the African continent using a continental version of the global hydrological model PCR-GLOBWB, which is based on a water balance approach. Results are compared with other independently computed evaporation products: the evaporation results from the ECMWF reanalysis ERA-Interim and ERA-Land (both based on the energy balance approach), the MOD16 evaporation product, and the GLEAM product. Three other alternative versions of the PCR-GLOBWB hydrological model were also considered. This resulted in eight products of actual evaporation, which were compared in distinct regions of the African continent spanning different climatic regimes. Annual totals, spatial patterns and seasonality were studied and compared through visual inspection and statistical methods. The comparison shows that the representation of irrigation areas has an insignificant contribution to the actual evaporation at a continental scale with a $0.5^{\circ}$ spatial resolution when averaged over the defined regions. The choice of meteorological forcing data has a larger effect on the evapo-
\end{abstract}

ration results, especially in the case of the precipitation input as different precipitation input resulted in significantly different evaporation in some of the studied regions. ERA-Interim evaporation is generally the highest of the selected products followed by ERA-Land evaporation. In some regions, the satellite-based products (GLEAM and MOD16) show a different seasonal behaviour compared to the other products. The results from this study contribute to a better understanding of the suitability and the differences between products in each climatic region. Through an improved understanding of the causes of differences between these products and their uncertainty, this study provides information to improve the quality of evaporation products for the African continent and, consequently, leads to improved water resources assessments at regional scale.

\section{Introduction}

Evaporation is one of the most important fluxes in the hydrological cycle. Recently, there has been a wide interest in estimating evaporation fluxes on a continental and global scales for a variety of purposes (van der Ent et al., 2010; Teuling et al., 2009; Miralles et al., 2011a; Vinukollu et al., 2011; Mu et al., 2011; Mueller et al., 2011, 2013; Jiménez et al., 2011). The accurate estimation of these fluxes on large scales has, however, always been a difficult issue. Direct measurements of evaporation are only possible over small regions, e.g. using flux towers, and are limited to only few sites, particularly 
in some developed regions. FLUXNET ${ }^{1}$ coordinates regional and global analysis of observations $\left(\mathrm{CO}_{2}\right.$, water and energy fluxes) from micrometeorological tower sites. Most of the existing global products are verified only in particular regions with available data, generally in North America and Europe (Mu et al., 2011; Alton et al., 2009; Zhang et al., 2010; Miralles et al., 2011b). Some studies have evaluated the developed global evaporation product with evaporation estimates by subtracting runoff from the precipitation (Vinukollu et al., 2011; Zhang et al., 2010). Few studies have compared the results of different evaporation products. Vinukollu et al. (2011) compared results of six evaporation products (from three process-based models forced with two radiation data sets) by computing the ensemble mean and product range globally, and by comparing the annual totals of each product over latitude bands. They found the highest uncertainties between the products in tropical and subtropical monsoon regions including the Sahel. They show that the model ensemble tends to overestimate the inferred evaporation values (inferred as $P-Q$ ). They indicate that no single model does better than any other globally, and that overall all data sets are likely to be high, which may be due to lack of soil moisture limitation in the models.

The LandFlux initiative, supported by GEWEX (http:// www.gewex.org/) is clearly dedicated to evapotranspiration. In the framework of this initiative, several global evaporation data sets were evaluated and compared (Jiménez et al., 2011; Mueller et al., 2011), and global merged benchmarking evaporation products were derived (Mueller et al., 2013). Mueller et al. (2013) derived their benchmark evaporation product using 40 distinct data sets over a $17 \mathrm{yr}$ period (1989-2005) and 14 data sets over a seven year period (1989-1995) derived from diagnostic data sets, landsurface models, and reanalysis data. Ghilain et al. (2011) present the instantaneous (MET) and daily (DMET) evaporation products developed in the framework of EUMETSAT's Land Surface Analysis Satellite Application Facility (LSASAF). The MET and DMET products became operational in August 2009 and November 2010 respectively, and were satisfactorily validated against ground observations in Europe. The products were compared with models from ECMWF and from the Global Land Data Assimilation System (GLDAS) in Africa and parts of South America. This comparison showed that the spatial correlation of the products with ECMWF remained very high (85 to $95 \%$ ) and was constant throughout the whole year. However, they found that for northern and southern Africa their product (LSA SAF MET) exhibited lower estimates than ECMWF and GLDAS, with the difference with the ECMWF product being the largest (EUMETSAT, 2011). To our knowledge, none of the existing studies regarding large-scale evaporation has focused on the African continent. This work introduces a thorough comparison of different evaporation products over diverse African regions and climates.

In most cases, estimations of actual evaporation at a continental scale rely on complementary products such as (i) remote sensing, (ii) continental-scale hydrological models, or (iii) land-surface models. However, in some ways, these three different data sources follow different theoretical basis or approaches in estimating evaporation. For example there is a significant difference in the model objective of land-surface models and hydrological models. The former focus on providing boundary conditions (turbulent fluxes) to the atmosphere (mainly focusing on the energy balance) whereas the latter focus on closing the terrestrial water balance (Overgaard et al., 2006). In this study the class of hydrological models is represented by PCR-GLOBWB (van Beek and Bierkens, 2009). This model is based on the water balance approach that focuses on water availability and vertical and lateral transfer of water. The class of land-surface models is represented by the ECMWF reanalysis ERA-Land (Balsamo et al., 2012, ERAL) and ERA-Interim (ERAI, Dee et al., 2011) using a land-surface model that describes the vertical exchanges of heat and water between the atmosphere and the land surface on a grid point scale (Balsamo et al., 2011a). The evaporation results of both are compared with the remote-sensing-based data (i.e. the MOD16 product by Mu et al. (2011, 2007), and the GLEAM product by Miralles et al. (2011a, b)). It is worth clarifying that PCR-GLOBWB and ERAL evaporation come from offline (or stand alone) simulations, while ERAI is a coupled land-atmosphere reanalysis product. The quality of the individual products can be influenced by different climatic regions. Therefore, in this study we differentiated the hydro-climatic regions in Africa and the comparison is carried out for each region.

The main aim of the present paper is to compare different actual evaporation estimates for the African continent in order to gain a better understanding of the disparities between the different products within defined regions and the possible causes of these differences (e.g. resulting from the meteorological input data or from the model structure in the derivation of actual evaporation). This comparison can serve as an indirect validation of methods or tools used in operational water resources assessments. In this study we do not intend to evaluate whether one product is better than the others but to discriminate areas where good consistency can be found between the results of the selected models in contrast to regions where model results diverge. We seek to provide an uncertainty range in the expected actual evaporation values for the defined regions. The understanding of this range can be useful in, for example, water resources management when estimating the water balance.

\footnotetext{
${ }^{1}$ http://fluxnet.ornl.gov/.
} 
Table 1. Summary of African evaporation products used in this study.

\begin{tabular}{|c|c|c|c|c|c|}
\hline $\begin{array}{l}\text { Evaporation } \\
\text { product }\end{array}$ & Provider & $\begin{array}{l}\text { Input } \\
\text { precipitation data }\end{array}$ & $\begin{array}{l}\text { Potential } \\
\text { evaporation - method }\end{array}$ & $\begin{array}{l}\text { Spatial } \\
\text { resolution }\end{array}$ & $\begin{array}{l}\text { Temporal } \\
\text { coverage }\end{array}$ \\
\hline (1) PCR-GLOBWB & This study $(*)$ & $\mathrm{ERAI}+\mathrm{GPCP}$ & Hargreaves & $0.5^{\circ}$ & 1 Jan 1979-31 Dec 2010 \\
\hline (2) PCR_PM & This study ${ }^{(*)}$ & $\mathrm{ERAI}+\mathrm{GPCP}$ & Penman-Monteith & $0.5^{\circ}$ & 1 Jan 1979-31 Dec 2010 \\
\hline (3) PCR_TRMM & This study $(*)$ & TRMM 3B42 v6 & Hargreaves & $0.5^{\circ}$ & Since 1 Jan 1998 \\
\hline (4) PCR_Irrig & This study ${ }^{(*)}$ & ERAI + GPCP & Hargreaves & $0.5^{\circ}$ & 1 Jan 1979-31 Dec 2010 \\
\hline (5) ERAI & ECMWF & ERAI & No PE input & $\sim 0.7^{\circ}$ & 1 Jan 1979-near-real-time \\
\hline (6) ERAL & ECMWF & $\mathrm{ERAI}+\mathrm{GPCP}$ & No PE input & $\sim 0.7^{\circ}$ & 1 Jan 1979-31 Dec 2010 \\
\hline (7) MOD16 & University of Montana & NASA's GMAO & Penman-Monteith & $1 \mathrm{~km}$ & Since 1 Jan 2000 \\
\hline (8) GLEAM & VU Amsterdam & PERSIANN & Priestley and Taylor & $0.25^{\circ}$ & Since 1 Jan $1998^{(* *)}$ \\
\hline
\end{tabular}

(*) The evaporation product resulted from the PCR-GLOBWB hydrological model (van Beek and Bierkens, 2009) forced with different (varying) input data and conditions.

${ }^{(* *)}$ The temporal coverage of GLEAM depends on which inputs are used to run the methodology. Here the record is restricted by the availability of PERSIANN precipitation.

\section{Data and methods}

\subsection{Evaporation data sets}

This section describes briefly the evaporation products used in this study (see Table 1 for a summary). These are all global products extracted for Africa at a daily temporal resolution, with the exception of the MOD16 product, which is a monthly product. The period chosen in this study for the evaporation comparison is 2000-2010, which is the period common to all the products.

Four of the evaporation products considered in this study are based on the PCR-GLOBWB hydrological model (see Table 1, these products are indicated by the PCR prefix) with differences in the input data or the addition of specific processes to assess their impact on the resulting evaporation product. Each of the products is described in detail below. The description of the first product based on PCR-GLOBWB also presents a general explanation of the PCR-GLOBWB hydrological model with the selected forcing data. We then describe the other PCR-GLOBWB-based products by emphasizing only the differences to the first product.

\subsubsection{PCR-GLOBWB}

The PCR-GLOBWB evaporation product was calculated by means of a continental-scale version of the distributed global hydrological model PCR-GLOBWB (van Beek and Bierkens, 2009), which was set up for the African continent in the context of the FP7 EU DEWFORA project (Improved Drought Early Warning and Forecasting to strengthen preparedness and adaptation in Africa). PCR-GLOBWB is used at a global scale for a variety of purposes: seasonal prediction, quantification of the hydrological effects of climate variability and climate change, to compare changes in terrestrial water storage with observed anomalies in the Earth's gravity field and to relate demand to water availability in the context of water scarcity (see Sperna Weiland et al., 2012; van Beek et al., 2011; Wada et al., 2011; Droogers et al., 2012; Sperna Weiland et al., 2011).

PCR-GLOBWB is a process-based model that is applied on a cell-by-cell basis $\left(0.5^{\circ} \times 0.5^{\circ}\right)$. PCR-GLOBWB is forced with potential evaporation, and actual evaporation is derived through simulation. Initially, the model converts potential reference evaporation $E_{0}$ into potential soil evaporation $\left(\mathrm{ES}_{0}\right)$ and potential transpiration $\left(T_{0}\right)$ by introducing monthly and minimum crop factors. The crop factors are specified on a monthly basis for short and tall vegetation fractions, as well as for the open water fraction within each cell. These crop factors are calculated as a function of the leaf area index (LAI) as well as of the crop factors for bare soil and under full cover conditions (van Beek et al., 2011). Monthly climatology of LAI is estimated for each GLCC (Global Land Cover Characterization) type, using LAI values per type for dormancy and growing season from Hagemann et al. (1999). LAI is then used to compute the crop factor per vegetation type according to the FAO guidelines (Allen et al., 1998). We then updated the crop factors for irrigated areas using the global data set of Monthly Irrigated and Rainfed Crop Areas around the year 2000 (MIRCA2000) (Portmann et al., 2008, 2010). Interception evaporation reduces potential transpiration, and the availability of soil moisture storage is responsible for the reductions of the potential bare soil evaporation and transpiration. The potential bare soil evaporation over the unsaturated area is only limited by the unsaturated hydraulic conductivity of the upper soil layer. For the saturated area the rate of evaporation cannot exceed the saturated hydraulic conductivity of the upper soil layer. Transpiration only takes place for the unsaturated fraction of the cells and depends on the total available moisture in the soil layers (van Beek and Bierkens, 2009).

The model is described in full detail elsewhere (van Beek et al., 2011; van Beek and Bierkens, 2009). We hereby describe the forcing data applied in the first version of the model used in this study (product 1). Three other evaporation products were derived also from this model with changes in 
either the forcing data or in the model structure (products 2 , 3 and 4 , Table 1).

\section{Meteorological forcing}

The model is directly forced with daily precipitation, temperature and reference potential evaporation as calculated from other meteorological variables $(2 \mathrm{~m}$ temperature, $2 \mathrm{~m}$ dewpoint temperature, surface pressure, wind speed, and net radiation). Meteorological forcing was obtained from the ERA-Interim (ERAI) reanalysis data of the past $32 \mathrm{yr}$ (19792010). The ERAI precipitation data used in this study is available at a resolution of approximately $0.7^{\circ}$ and was corrected with GPCP v2.1 (product of the Global Precipitation Climatology Project) to reduce the bias when compared to measured products (Balsamo et al., 2010; Szczypta et al., 2011). The GPCP v2.1 is available globally at $2.5^{\circ} \times 2.5^{\circ}$ resolution with a monthly frequency, covering the period from 1979 to September 2009. It combines the precipitation information available from several sources (satellite data, rain gauge data, etc.) into a merged product (Szczypta et al., 2011; Huffman et al., 2009). From September 2009 to December 2010, the mean monthly ERAI precipitation was corrected using a mean bias coefficient based on the climatology of the bias correction coefficients used for the period 1979-2009. While this only corrects for systematic biases, this was the only option available at the time, as a new version of GPCP (version 2.2) was not available. The meteorological forcing was applied with the same spatial resolution of $0.5^{\circ}$ as the model, using bilinear interpolation to downscale from the ERAI grid to the model grid, and is assumed to be constant over the grid cell.

\section{Reference potential evaporation from reanalysis data}

The PCR-GLOBWB model requires reference potential evaporation as a meteorological input, and this therefore needs to be estimated externally. There are several approaches to estimate potential evaporation, with diverse levels of data requirements and complexity, with different temporal scales, physically based and empirical, developed under specific regions or climates. The Hargreaves equation (input parameters: daily minimum, maximum and mean temperature and extraterrestrial radiation) was used because it has the advantage that it can be applied in data scarce regions, which is the case for several regions in Africa. Droogers and Allen (2002) compared Penman-Monteith and Hargreaves reference evaporation estimates on a global scale and found very reasonable agreement between the two methods $\left(R^{2}=0.895, \mathrm{RMSD}=0.81\right)$. They suggest that the Hargreaves formula should be considered in regions where accurate weather data cannot be expected. The Hargreaves method requires less parameterization, with the disadvantage that it is less sensitive to climatic input data, with a possi- bly reduction of dynamics and accuracy. However, it leads to a notably smaller sensitivity to error in climatic inputs (Hargreaves and Allen, 2003). Moreover, Sperna Weiland et al. (2012) studied several methods to calculate daily global reference potential evaporation from Climate Forecast System Reanalysis (CFSR) data from the National Center for Atmospheric Research, for application in a hydrological model study. They compared six different methods and found a recalibrated form of the Hargreaves equation (increasing the multiplication factor of the equation from 0.0023 to 0.0031 ) to outperform the other alternatives.

\subsubsection{PCR_PM}

The PCR_PM evaporation product results from forcing the PCR-GLOBWB hydrological model with PenmanMonteith reference potential evaporation. The PenmanMonteith method is one of the most widely used for the estimation of potential evaporation. Although this formula is in general highly recommended by the FAO and is considered to be one of the most physically based methods, it is impacted by the site aridity and is reported to underestimate the potential evaporation in some regions of Africa and other arid regions (Sperna Weiland et al., 2012; Hargreaves and Allen, 2003). Nevertheless, in this study we estimate the potential evaporation with the Penman-Monteith method using input variables derived from the ERAI data. This is then used to force the PCR-GLOBWB hydrological model to assess the difference in the actual evaporation resulting from the different inputs in reference potential evaporation. This product differs from the first product (PCR-GLOBWB) only in the forcing potential evaporation data set used.

\subsubsection{PCR_TRMM}

This evaporation product (PCR_TRMM) results from the PCR-GLOBWB hydrological model simulation, but forced with TRMM 3B42 v6 precipitation data, which has finer spatial resolution and is independent of the ERAI forecasting platform. Other meteorological inputs, including potential evaporation are as in the product 1 version of the PCRGLOBWB model. Including this product in the comparison allows for assessing the impact that the precipitation forcing has on the resulting actual evaporation. The TRMM 3B42 v6 precipitation data was chosen from the available satellitebased rainfall estimates following the results of a recent study that validated six of these products and one reanalysis product (ERA-Interim) over four African basins (Thiemig et al., 2012), and found TRMM 3B42 together with RFE 2.0 (NOAA African Precipitation Estimation Algorithm) to be the most accurate products when compared to ground data. 


\subsubsection{PCR_Irrig}

This product (PCR_Irrig) is also the result of the PCRGLOBWB hydrological model when irrigation is included in the model structure. It was introduced in the study as some African countries such as Egypt, Morocco, Sudan and South Africa contain large irrigation areas. In South Africa, for example, there is a high density of small reservoirs for irrigation purposes (see McClain, 2012). The different components of evaporation (soil evaporation, transpiration and open water evaporation from reservoirs) are expected to increase as a result of irrigation practices, reaching potential evaporation rates under optimal irrigation practices. Moreover, a recent study by van Beek et al. (2011) suggested that the PCR-GLOBWB hydrological model might underestimate evaporation given that the default model does not explicitly consider irrigated areas. They compared the PCRGLOBWB evaporation results with the reanalyses ERA-40 (reanalysis by ECMWF, a previous version of the ERAInterim) evaporation and found ERA-40 evaporation to be consistently higher than the evaporation data simulated by PCR-GLOBWB. They attributed these differences to irrigation, as they indicated that ERA-40 (which includes data assimilation) accounts implicitly for irrigation by decreasing the temperature to compensate for the energy loss as latent heat. The original version of PCR-GLOBWB, on the other hand, includes irrigated areas using crop factors, but actual evaporation cannot exceed the available soil moisture as the additional contribution due to irrigation is not modelled. The difference between the two actual evaporation products represent the transpiration of the water applied (van Beek et al., 2011).

To include the influence of irrigation the original PCRGLOBWB hydrological model was adapted. The irrigation requirement for the irrigated crop area within a cell is supplied through the storage of freshwater in the cell. For each cell where irrigation takes place, it is assumed that at least a small farm reservoir is included and that this provides sufficient storage to satisfy the demand. The irrigated area within each cell, water requirements and irrigation cropping patterns are extracted from the "Global map of irrigated areas" from Siebert et al. (2007) and FAO (1997). This modified version of the hydrological model serves to assess the impact of adding irrigation in the model structure on the actual evaporation results.

\subsubsection{ERAI}

ERA-Interim (ERAI) is a global atmospheric reanalysis produced by the European Centre for Medium-Range Weather Forecasts (ECMWF) which covers the period from January 1979 to present date with a horizontal resolution of approximately 0.7 degrees and 62 vertical levels. A comprehensive description of the ERAI product is available in Dee et al. (2011). The ERAI evaporation is the result from the coupled land-atmosphere simulations. The ERAI land component is the model TESSEL (Van den Hurk et al., 2000) that is coupled to the atmospheric model, therefore being forced (and providing fluxes to the atmosphere) with the ERAI forecasts of near-surface conditions (temperature, humidity, pressure and wind speed) and downward energy and water fluxes (precipitation, solar and thermal radiation). In ERAI, the LAI is used as fixed fields with no inter-annual variability.

\subsubsection{ERAL}

ERA-Land (ERAL, Balsamo et al., 2012) is a global landsurface data set covering the period 1979-2010. ERAL is a land-surface-only simulation (offline) carried out with HTESSEL (Balsamo et al., 2011a, b), an updated version of TESSEL (that was used in ERAI), with meteorological forcing from ERAI and precipitation adjustments based on GPCP. HTESSEL computes the land-surface response to the near-surface atmospheric conditions forcing, and estimates the surface water and energy fluxes and the temporal evolution of soil temperature, moisture content and snowpack conditions. At the interface to the atmosphere each grid box is divided into fractions (tiles), with up to six fractions over land (bare ground, low and high vegetation, intercepted water, shaded and exposed snow). The grid box surface fluxes are calculated separately for each tile, leading to a separate solution of the surface energy balance equation and the skin temperature. The latter represents the interface between the soil and the atmosphere. Below the surface, the vertical transfer of water and energy is performed using four vertical layers to represent soil temperature and moisture. Soil heat transfer follows a Fourier law of diffusion, modified to take into account soil water freezing/melting. Water movement in the soil is determined by Darcy's Law, and surface runoff accounts for the sub-grid variability of orography (Balsamo et al., 2009). HTESSEL is part of the integrated forecast system at ECMWF with operational applications ranging from short-range to monthly and seasonal weather forecasts. The LAI in ERAL was prescribed as a mean annual climatology, as described by Boussetta et al. (2012).

ERAI and ERAL differ mainly in three aspects: (i) landsurface model - TESSEL in ERAI and HTESSEL in ERAL; (ii) coupling to the atmosphere - ERAI coupled and ERAL land-surface-only simulations (no feedback to the atmosphere forced with corrected precipitation); and (iii) data assimilation - none in ERAL while ERAI soil moisture assimilation scheme corrects soil moisture in the first three layers based on the $6 \mathrm{~h}$ atmospheric analysis increments of specific humidity and temperature at the lowest model level (Douville et al., 2000). While the first two points are difficult to evaluate, the impact of soil moisture data assimilation in ERAI can be evaluated by calculating the assimilation increments: i.e. the amount of soil moisture added (or removed) by the data assimilation system. 


\subsubsection{MOD16}

Remote sensing provides an indirect method to estimate global actual and potential evaporation. MOD16 is described in detail by $\mathrm{Mu}$ et al. $(2011,2007)$, and computes potential and actual evaporation using MODIS (Moderate resolution Imaging Spectroradiometer) land cover, albedo, LAI, an Enhanced Vegetation Index (EVI), and a daily meteorological reanalysis data set from NASA's Global Modelling and Assimilation Office (GMAO) as inputs for regional and global evaporation mapping and monitoring (Mu et al., 2011). This method is an adaptation of a previous version of the evaporation algorithm by $\mathrm{Mu}$ et al. (2007), which is based on the remotely sensed evaporation model developed by Cleugh et al. (2007).

Mu et al. (2011) computed potential evaporation with the Penman-Monteith method driven by GEOS-5 daily meteorological reanalysis inputs and MODIS derived vegetation data: land-surface temperature, LAI, gross primary productivity and vegetation indices were extracted from four different MODIS products. To derive actual from potential evaporation, Mu et al. (2007) include multipliers to halt plant transpiration and soil evaporation as follows: low temperatures and water stress (due to high vapour pressure deficit) limit the transpiration flow, and soil evaporation is limited by a complementary relationship hypothesis which defines land-atmospheric interactions from vapour pressure deficit and relative humidity (Mu et al., 2007).

This product has been validated against actual measurements in several regions. Mu et al. (2011) evaluated their algorithm using evaporation observations at 46 eddy covariance flux towers in the United States and Canada. In their paper they present the root mean square error (RMSE), correlation, and Taylor skill score for each flux tower, and they report that the average mean absolute bias values are $24.1 \%$ of the evaporation measurements. Kim et al. (2012) validated MOD16 global terrestrial evaporation products at 17 flux tower locations in Asia and found good agreement only at five locations ( $r=0.50$ to 0.76 , bias $=-1.42$ to $1.99 \mathrm{~mm}$

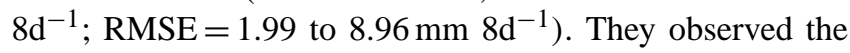
best performance of the MOD16 evaporation algorithm at sites with forested land cover. They observed poor performance at sites with grassland cover in arid and polar climates. The MODIS derived potential and actual evaporation are available online (http://www.ntsg.umt.edu/project/ mod16, data set retrieved in April 2012) with a resolution of $1 \mathrm{~km}$ and as with most standard MODIS Land products, it uses the Sinusoidal grid tiling system in which the tiles are $10^{\circ} \times 10^{\circ}$ at the equator (USGS, 2012). We created the mosaic for each month obtaining one monthly map for the entire continent, and scaled it up to a resolution of $0.5^{\circ}$ $(\sim 50 \mathrm{~km})$ using the cubic convolution resampling as suggested by Keys (1981) and Liu et al. (2007).

\subsubsection{GLEAM}

GLEAM (Global Land Evaporation: the Amsterdam Methodology) is a method to derive global evaporation from a wide range of satellite observations that was developed by the VU University of Amsterdam (Miralles et al., 2011a, b). The version of the product used here has a spatial resolution of 0.25 degrees latitude-longitude, and it is forced with PERSIANN (Precipitation Estimation from Remotely Sensed Information using Artificial Neural Networks) precipitation data, soil moisture and vegetation optical depth data retrieved from the NASA-LPRM (Land Parameter Retrieval Model $^{2}$ - Owe et al., 2008), radiation fluxes from ERA-Interim, air temperature from AIRS (Atmospheric InfraRed Sounder) gap-filled with ISCCP (International Satellite Cloud Climatology Project - Rossow and Schiffer, 1999), and snow water equivalents from NSIDC (National Snow and Ice Data Center - Armstrong et al., 2007). GLEAM uses a modified Priestley and Taylor (PT) model, in combination with an evaporative stress module and a Gash analytical model of rainfall interception (Miralles et al., 2010), to combine the above-mentioned satellite-observable variables to derive evaporation. The GLEAM algorithm has been recently validated using measurements from 163 eddy covariance stations and 701 soil moisture sensors (Miralles et al., 2013).

\subsection{Definition of regions}

In this paper we aim to compare the different sets of evaporation results in defined African regions. With this purpose, we divided the African continent in regions based on similar aridity conditions and annual precipitation cycles. First, we divided the African continent based on climatic classes. The classification of the different climates was done following the definition of the UNEP (1997) and the Global Aridity Index (Global-Aridity) data set produced by Zomer et al. (2008). This is published online in the Consultative Group for International Agriculture Research Consortium for Spatial Information (CGIAR-CSI) website (CGIAR CSI Consortium for Spatial Information, 2010). The Global-Aridity data set is provided for non-commercial use in standard ARC/INFO Grid format, at $30 \operatorname{arcsec}(\sim 1 \mathrm{~km}$ at equator). Zomer et al. (2008) calculated a global map of the mean Aridity Index (AI) from the $1950-2000$ period at $0.5^{\circ} \mathrm{spa}-$ tial resolution as

$\mathrm{AI}=\mathrm{MAP} / \mathrm{MAE}$

where MAP is the Mean Annual Precipitation $\left(\mathrm{mm} \mathrm{yr}^{-1}\right)$ and $\mathrm{MAE}$ is the Mean Annual Potential Evaporation $\left(\mathrm{mm} \mathrm{yr}^{-1}\right)$.

\footnotetext{
${ }^{2} \mathrm{http} / / / \mathrm{gcmd}$. nasa.gov/records/GCMD_GES_DISC_LPRM_ AMSRE_SOILM2_V001.html The data are derived from different satellite sensors: SSMI before mid-2002 and AMSR-E after mid-2002.
} 
Table 2. Generalized climate classification scheme for GlobalAridity values (UNEP, 1997).

\begin{tabular}{cc}
\hline Aridity Index value & Climate class \\
\hline$<0.03$ & Hyper arid \\
$0.03-0.2$ & Arid \\
$0.2-0.5$ & Semi-arid \\
$0.5-0.65$ & Dry sub-humid \\
$>0.65$ & Humid \\
\hline
\end{tabular}

In their study, they computed the mean Aridity Index using the data available from the WorldClim Global Climate Data (Hijmans et al., 2005) as input parameters and the Hargreaves equation to model Potential Evaporation globally.

For the purpose of this study, we processed this AI global data set in GIS, trimmed it for the African continent, classified it into six classes according to the UNEP classification (1997) (see Table 2), and scaled it up to a grid resolution of $0.5^{\circ}$ in agreement with the hydrological model grid. For upscaling we used the area-majority technique, in which the pixel value that is common to majority of the input pixels (because each pixel has equal area) is assigned to the output pixel. Figure 1 presents the resulting map of climate classes for the African continent at the scaled up resolution.

Different regions of the continent have very diverse annual precipitation cycles despite being classified in the same climate class. This is the case, for example, of the arid climate in the Horn of Africa and in south-western Africa, one characterized by two rainy seasons and another by only one rainy season in a year (see McClain, 2012). This is why most studies that divide Africa in regions usually consider sub-regions that capture the mean annual cycle of precipitation of the region (single or multiple rainy seasons, precipitation interannual variability, etc.). Sylla et al. (2010) divided the continent in eight regions, namely: West Sahel, East Sahel, Guinea Coast, north equatorial central Africa, Horn of Africa, south equatorial central Africa, central southern Africa, and South Africa. These regions have a uniform annual cycle of precipitation but do not distinguish between the different climatic classes within the region. The total annual precipitation in the Sahel region can be much higher for the semi-arid climate than for the arid climate (both contained in the Sahel region).

This study differentiates in regions characterized by both the regional location (e.g. Horn of Africa or southern Africa) and the climatic class within the region. We merged some of the regions defined by Sylla et al. (2010) which had very similar mean annual cycles of precipitation (e.g. East Sahel with West Sahel, central southern Africa with South Africa), to reduce the number of sub-regions from eight to five. To these we added the Mediterranean region. Six location regions were therefore defined and are presented in Fig. 2. Finally each location region was divided in their climatic class

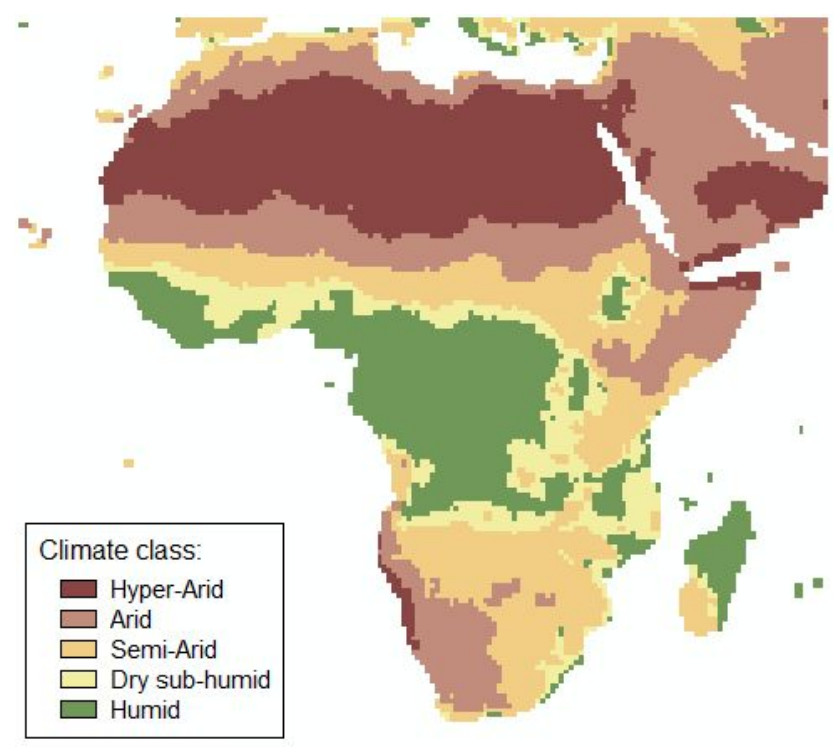

Fig. 1. Derived climate classes for the African continent with a resolution of 0.5 degrees.

and the resulting regions are shown in Fig. 3. The Sahara Desert region was not considered in this study due to the negligible evaporation rates year round by virtue of hyperarid conditions that result in very low water content in the soil.

\subsection{Comparison of evaporation products}

The common period January 2000 to December 2010 was selected to compare the evaporation products for this study. We first evaluate the difference between the crop-specific potential evaporation products that are used in this study for the derivation of the actual evaporation products (if applicable). The crop-specific potential evaporation can be defined as the amount of evaporation that would occur for a given crop if there is sufficient water available. The crop-specific potential evaporation, $\mathrm{PE}_{\mathrm{c}}\left(\mathrm{mm} \mathrm{day}^{-1}\right)$ is computed within the PCR-GLOBWB model from: $\mathrm{PE}_{\mathrm{c}}=k_{\mathrm{c}} \times \mathrm{PE}_{\mathrm{r}}$ where $\mathrm{PE}_{\mathrm{r}}$ $\left(\mathrm{mm} \mathrm{day}^{-1}\right)$ is the reference potential evaporation and $k_{\mathrm{c}}$ is a crop factor (dimensionless) (van Beek et al., 2011). The comparison between the actual evaporation products is then carried out at a monthly temporal scale as well as within the defined regions in the continent.

Continental maps of long-term average annual cropspecific potential evaporation were computed for each product. To compare two of the evaporation products on a gridded basis, and considering the absence of ground data to compare to, we defined the relative mean difference (RMD (\%)) of the two crop-specific potential evaporation products as

$\mathrm{RMD}=\frac{\left(E_{1}-E_{2}\right)}{\bar{E}} \times 100 \%$, 


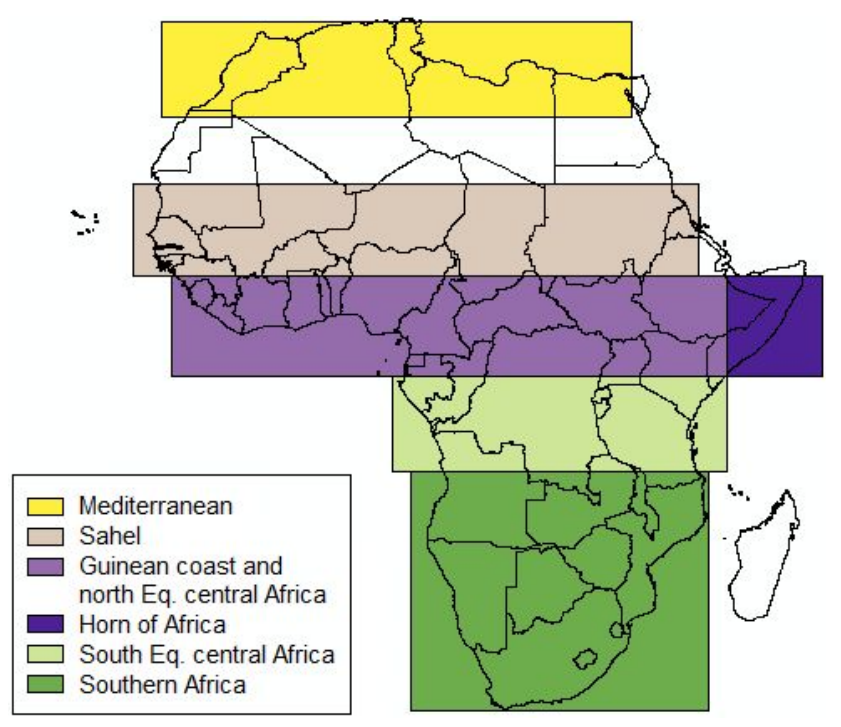

Fig. 2. Location regions in Africa based on similarity of annual precipitation cycle (based on Sylla et al., 2010).

where $E_{1}$ and $E_{2}$ is the annual crop-specific potential evaporation $\left(\mathrm{mm} \mathrm{yr}^{-1}\right)$ data set of 1 or 2 , respectively, and $\bar{E}$ is the mean crop-specific potential evaporation $\left(\mathrm{mm} \mathrm{yr}^{-1}\right)$ of products $E_{1}$ and $E_{2}$.

RMD indicates which product is consistently higher than the other, and the relative magnitude of the difference between them (compared with the average value). This indicator seems to be a fair way of estimating the relative difference as none of the available products represents ground truth. Indicators showing absolute differences are not useful as the same absolute difference can be relatively large for areas with low actual evaporation values (arid areas), and relatively low for areas with high actual evaporation values (humid areas).

We also computed continental maps of long-term average actual evaporation for each product to allow for a visual perception of the spatial variability of the continental evaporation for each product, and between products. Moreover, to make the analysis quantitative, we created an Evapotranspiration Multiproduct (EM) as the median of the considered products and we computed the relative mean bias (RMB (\%)) between each product and the EM. In this case we considered the EM as the "observations", and the RMB was defined similarly to the RMD as follows:

$\mathrm{RMB}=\frac{\left(E_{i}-\mathrm{EM}\right)}{\mathrm{EM}} \times 100 \%$,

where $E_{i}$ is the annual actual evaporation $\left(\mathrm{mm} \mathrm{yr}^{-1}\right)$ data set $i$ and EM is the annual actual evapotranspiration multiproduct $\left(\mathrm{mm} \mathrm{yr}^{-1}\right)$.

Subsequently, for each region the annual totals of each evaporation product were computed and the seasonality of the different products was studied and compared with the EM. The mean annual anomalies of each product with re-

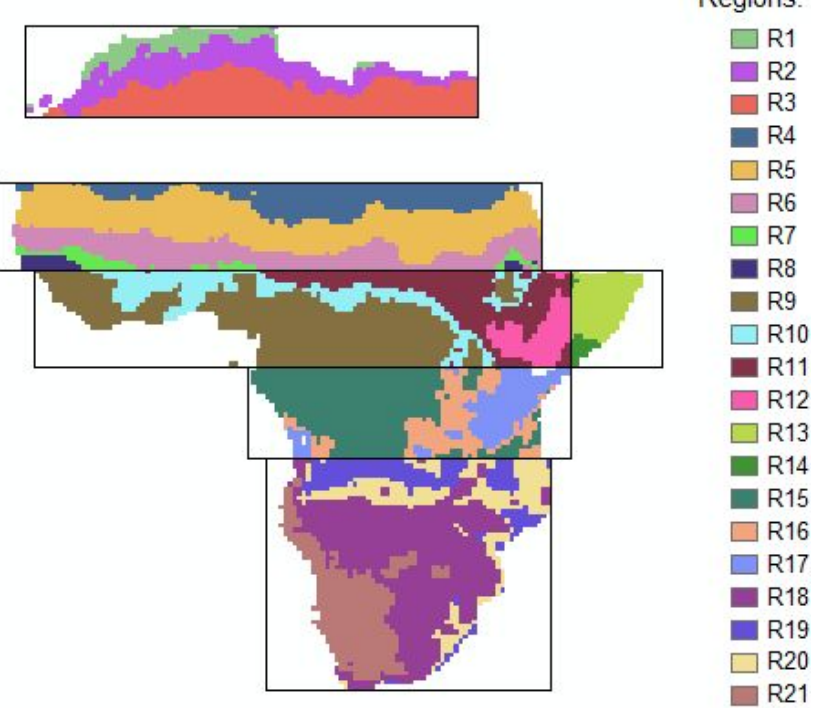

Fig. 3. Derived "regions" characterized by both the regional location and the climatic class within the region.

spect to the EM are presented for each region, and the variation of mean monthly actual evaporation was plotted for each product within each region and compared through visual inspection. The statistics of each evaporation product were then plotted for each region by means of Taylor diagrams of monthly evaporation and a box plot diagram of seasonal evaporation. The box plots, presented in Appendix A, are displayed for the wet and the dry seasons.

\section{Results}

\subsection{Comparison of potential evaporation products}

PCR-GLOBWB model and MOD16 compute the actual evaporation fluxes from the crop-specific potential evaporation (PE) and limitations due to water availability and/or low temperatures. We hereby present three potential evaporation estimates. We computed the first two (for PCRGLOBWB) from the ERA-Interim reanalysis data using Penman-Monteith and Hargreaves methods. The third product, MOD16 PE, uses the Penman-Monteith method but is derived from NASA's Global Modelling and Assimilation Office (GMAO) meteorological data and MODIS maps.

Figure 4 presents the mean annual crop-specific potential evaporation for the period 2000-2010 based on (a) the Penman-Monteith method, and (b) the Hargreaves method, both derived from the ERA-Interim reanalysis data. Figure $4 \mathrm{c}$ presents the potential evaporation from the MOD16 product. The areas in grey in the MOD16 potential evaporation correspond to missing evaporation data in the MOD16 product. MOD16 does not include urban and barren areas since there 
a)

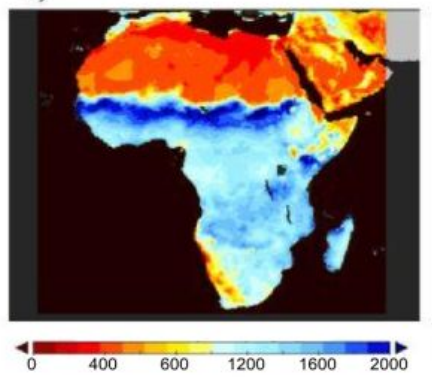

d)

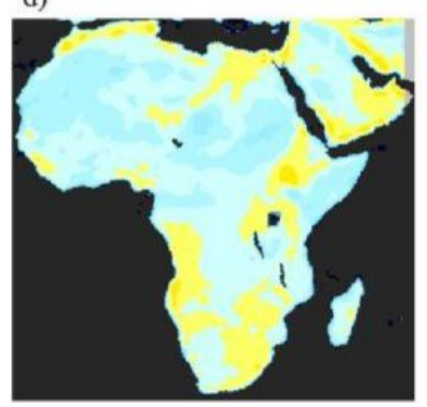

b)

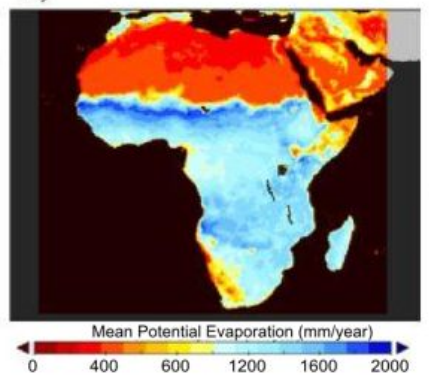

c)

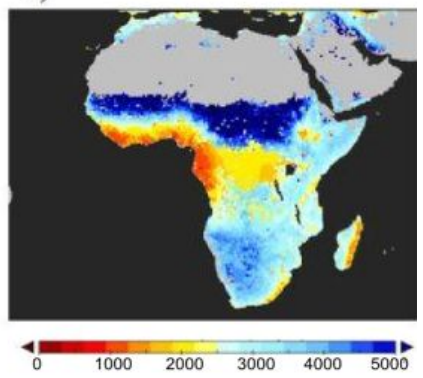

f)

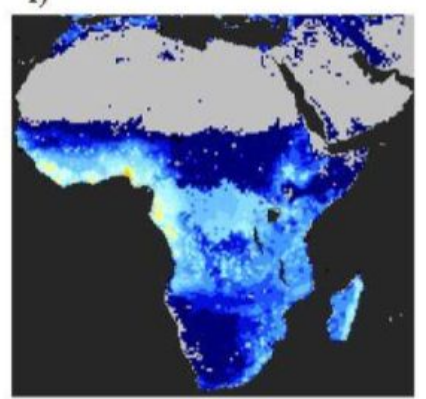

e)

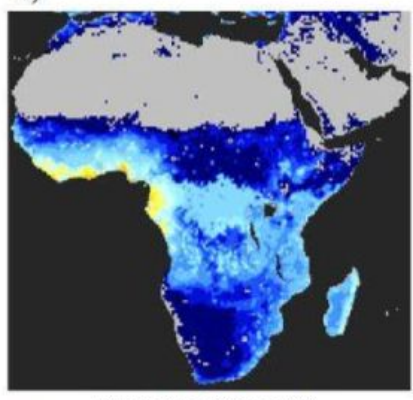

Relative Mean Difference (\%)

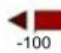

$-60$

$-20$

60

100

Fig. 4. On top: comparison of mean annual crop-specific potential evaporation computations for Africa with different methods: (a) PenmanMonteith, (b) Hargreaves and (c) MOD16 product (note that the grey area corresponds to missing data and that values are presented at another scale to improve visualization). On the bottom: relative mean difference (RMD) between (d) Penman-Monteith potential evaporation (PE) and Hargreaves PE, (e) MOD16 PE and Penman-Monteith PE, and (f) MOD16 PE and Hargreaves PE.

is no MODIS derived FPAR/LAI for these land cover types (Mu et al., 2011).

As can be seen in Fig. 4a and b, the potential evaporation derived from the Penman-Monteith equation and Hargreaves equation result in very similar values throughout the continent. The small differences are due to the different formulations of the method and the greater number of input parameters that Penman-Monteith requires, in comparison with the more simplified Hargreaves method. However, if we analyze at much smaller temporal and/or spatial scales the difference is likely to be more visible. The potential evaporation from MOD16, on the other hand, results in much higher values than the ones derived from the other two methods, especially for arid and semi-arid areas. The differences are such (a factor of 2 or up to 3 ) that the map needs to be presented with a different scale. The large differences between MOD16 potential evaporation product and the first product are a result of the differences in the input meteorological data (probably radiation) and vegetation data. The high disparities between the different potential evaporation products seem to be quite common, as also reported in Sperna Weiland et al. (2012), Weiß and Menzel (2008) and Kingston et al. (2009). Figure $4 \mathrm{~d}$ to $\mathrm{f}$ presents the relative mean difference (RMD) between each pair of products, and shows that the difference between the MOD16 potential evaporation product with the other two products is much smaller in humid areas than in arid and semi-arid areas. Penman-Monteith and Hargreaves products present RMD smaller than $20 \%$ throughout the continent.

We believe that the most plausible estimations for the potential evaporation could be somewhere in between, i.e. higher than Penman-Monteith and Hargreaves computed with ERA-Interim, but lower than MOD16. We also compared the Hargreaves reference potential evaporation (PEr) computed in this study and the Global Potential EvapoTranspiration (Global-PET) data set (Zomer et al., 2008), which was also computed using the Hargreaves method (selected among five different methods tested) using inputs from the WorldClim database. We observed that the PEr from the Global-PET is in general 20-30\% higher than the one computed in this study. This difference should be mainly due to the difference in temperature data sets used in the two estimates. In this comparison radiation does not influence the result, because same extraterrestrial radiation values are used in both cases. Regarding the MOD16 data set, little information was found on the validation of potential evaporation, Wang and Zlotnik (2012) found MOD16 to underestimate actual evaporation in wet years and to systematically overestimate potential evaporation across Nebraska. Overestimations of MOD16 PE might be due to biases in LAI values or in the input meteorological data from GMAO, such as overestimation of solar radiation. Zhao et al. (2006) compared 


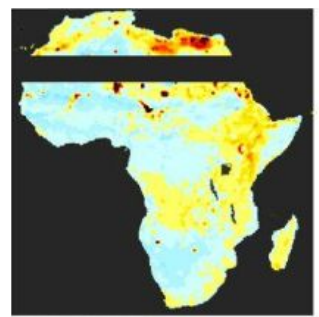

a) PCR-GLOBWB

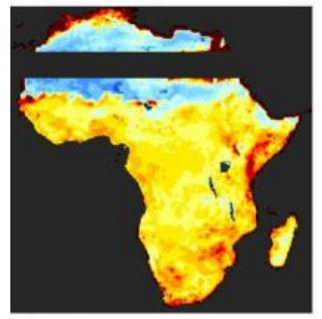

e) ERAI

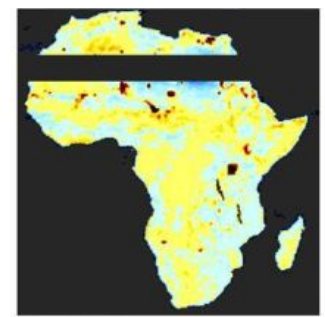

b) PCR_PM

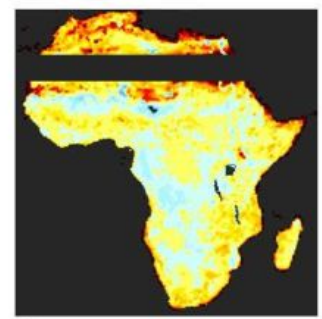

f) ERAL

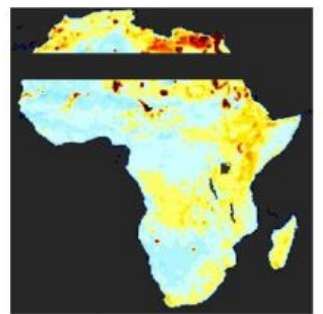

c) PCR_Irrig

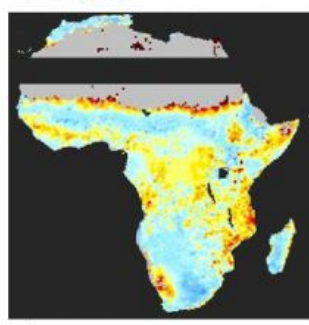

g) MOD16

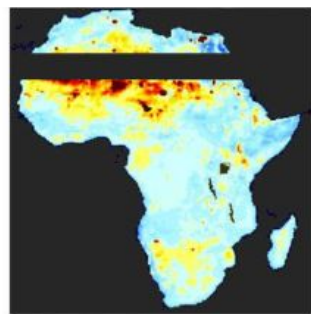

d) PCR_TRMM

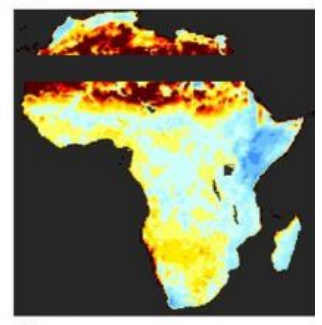

h) GLEAM

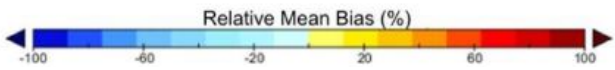

Fig. 5. Relative mean bias (RMB) between each product and the evaporation multiproduct (EM).

three known meteorological data sets: GMAO, ERA-40 from ECMWF and NCEP/NCAR to evaluate the sensitivity of MODIS global terrestrial gross and net primary production (GPP and NPP) to the uncertainties of meteorological inputs. They found that NCEP tends to overestimate surface solar radiation and underestimate both temperature and vapor pressure deficit (VPD), ECMWF has the highest accuracy but its radiation is lower in tropical regions, and the accuracy of GMAO lies in between. Their results show that the biases in the meteorological inputs can introduce significant error in the evaporation estimates.

\subsection{Comparison of actual evaporation products}

\subsubsection{Mean annual evaporation}

From the maps of mean annual evaporation for each product (not shown) it appears that the similarity between the different actual evaporation products is much higher than it is between the potential evaporation products. This suggests that the high variability introduced by the potential evaporation products is decreased in the derivation of actual evaporation. Figure 5 shows the maps of RMB between the mean annual actual evaporation of each product and the EM for the period 2000-2010. The RMB results in the highest values for the hyper-arid areas surrounding the Sahara Desert, region that was left out of this analysis due to its negligible actual evaporation values. On the continental scale the mean annual evaporation maps of PCR-GLOBWB and the PCR_Irrig products are almost identical. The difference is only apparent if compared on a much smaller scale. Therefore, PCR_Irrig product was not included in the EM product to avoid a double weight. ERAI is generally considerable above the EM, and for the remaining products the offset with the EM depends on the region. Over some water bodies higher evaporation values are noticeable in the products resulting from the PCRGLOBWB model when compared to the other products; open water evaporation is considered in the total actual evaporation in this model by means of crop factors, which are specified for the fractions: open water, short vegetation and tall vegetation for each cell. ERAI and ERAL only consider water bodies bigger than $3000 \mathrm{~km}^{2}$. For those grid points, only the energy balance is calculated and evaporation given as a free water surface with prescribed temperature. In GLEAM evaporation from the open water is considered as potential evaporation which is computed using Priestley and Taylor method. In MOD16 the contribution of lakes and rivers is not modelled, the evaporation therefore refers only to the land evaporation.

The annual anomalies of evaporation for each product with respect to the EM are presented in Fig. 6 for each region. The figure shows that ERAI evaporation product has the highest annual evaporation in the continent for almost every region with the exception of the hyper-arid and arid areas of the Mediterranean (R2 and R3) and Sahel (R4 and R5) regions, which border the Sahara Desert. Regarding the other evaporation products, in most cases they deviate from the EM for less than $100 \mathrm{~mm} \mathrm{yr}^{-1}$, with some few exceptions for MOD16, PCR_TRMM and GLEAM. The PCR-GLOBWB derived products forced with ERAI+GPCP precipitation are in almost every case close to the EM with the exception of humid Sahel (R8). PCR_TRMM product (PCR-GLOBWB model forced with TRMM precipitation data) is mostly lower than the EM (with the exception of the regions bordering 
the Sahara Desert), and closer to GLEAM, both forced with satellite rainfall products.

\subsubsection{Monthly and seasonal evaporation}

Figure 7 shows how the different evaporation products follow the intra-annual variability. For each region the mean monthly actual evaporation for every product and the EM is plotted. Seasonality is highlighted in the figure. We defined the seasons in the continent as dry and wet (from available literature (see Sylla et al., 2010; Jacovides et al., 2003), and the wet seasons for each region are indicated with a grey shadow in Fig. 7. The statistics of the monthly evaporation time series are presented in Taylor diagrams for some regions (see Fig. 8), which summarize the ratio of the standard deviation of each product and the EM, their root mean square difference (RMSD, showed in grey curves in Fig. 8), and the temporal correlation between each product and EM (based on the monthly values 2000-2010). The EM is considered here as the "reference" field. In the Taylor diagrams, products that are closer to the reference field have a "higher performance" than those which are farther, which in this study is interpreted as higher consistency between the products. Additionally, the statistics of the seasonal evaporation during the wet and dry seasons are presented graphically in Fig. A1 by means of a box plot diagram, showing the variability of the seasonal evaporation for each product within each region.

\section{Large-scale analysis}

In general terms, introducing the irrigation process in such a large-scale analysis does not result in visible changes as the evaporation is averaged over large regions. This can be observed in Figs. 6 and 7, where only in the Mediterranean region (R1, R2 and R3) and in the semi-arid Horn of Africa (R14) a slight deviation between the evaporation products with and without irrigation can be observed. In the regions where the larger irrigation areas in the continent are located (e.g. Nile Delta), the evaporation estimate when irrigation is considered is slightly higher than when irrigation is not considered. Introducing irrigation therefore does not significantly bring the evaporation closer to the ERA-Interim product in this regional analysis, as the higher evaporations in the comparatively small irrigated areas become insignificant when merging these values over larger areas without irrigation. In Fig. 7 PCR_Irrig product is in general overlapping with the PCR-GLOBWB product.

Another feature that is clearly visible from Figs. 6 and 7 is that for almost every region and season the ERAI product consistently has the highest evaporation. ERAL evaporation is in almost every case lower than that of ERAI. Figure 9 shows the mean annual soil moisture increments in ERAI. The increments are positive in most of the African continent, and partly explain the higher values of evaporation in ERAI when compared with ERAL. Drusch et. al. (2008) provide a detailed evaluation of the soil moisture analysis scheme used in ERAI pointing to some of the limitations (e.g. root zone soil moisture acts as a "sink" variable, in which errors are allowed to accumulate). They also present a new surface analysis scheme that is currently operational at ECMWF. The results in this study do not allow to clearly identify the main source of the differences between ERAI and ERAL, but qualitatively, ERAL is closer to the remaining data sets.

Likewise, higher evaporation values of GLEAM bordering the Sahara Desert are due to an error in the data assimilation of surface soil moisture in deserts that has been corrected in recent versions of the product (Diego Miralles, personal communication).

Regarding the impact that input meteorological data has on the resulting evaporation, we should look at both input precipitation and input potential evaporation. With respect to the input precipitation, there seems to be a general behaviour showing that the evaporation resulting from the model forced with TRMM precipitation is consistently lower than the evaporation that results when the model is forced with ERAI+GPCP (see Figs. 6 and 7). For almost every region, TRMM forced model results in lower evaporations than the EM. Regarding the potential evaporation input, it can be seen that the evaporation generated with PenmanMonteith potential evaporation is in every case very similar to the one forced with Hargreaves, which was expected due to the small differences in the forcing potential evaporation products. The MOD16 evaporation show poor consistency with the other products in arid areas as also observed by Kim et al. (2012); this can be seen in Fig. 7 (R2, R5, and R21) and Fig. 8 (R5). For other regions, mainly in the dry sub-humid and semi-arid climatic regions, MOD16 is more consistent with the other products (see Fig. 8).

A detailed comparison description for each region is presented in Appendix A. We hereby present a general interpretation of the impact of the input data and modelling parameterizations. A full in-depth study of these including the impact of parameter values is considered to be outside the scope of this paper.

\section{A. Effect of input meteorological data in the estimation of actual evaporation}

\section{i. Precipitation data}

The intensity of the forcing precipitation has a large influence in the simulated actual evaporation. ERAI precipitation corrected with GPCP in general compares well with observed data at a monthly basis and has good ability to estimate the peak locations, but it is known to overestimate the frequency of wet days and underestimate the daily highest intensities in some regions (e.g. Iberian Peninsula, BeloPereira et al., 2011). Thiemig et al. (2012) obtained similar 


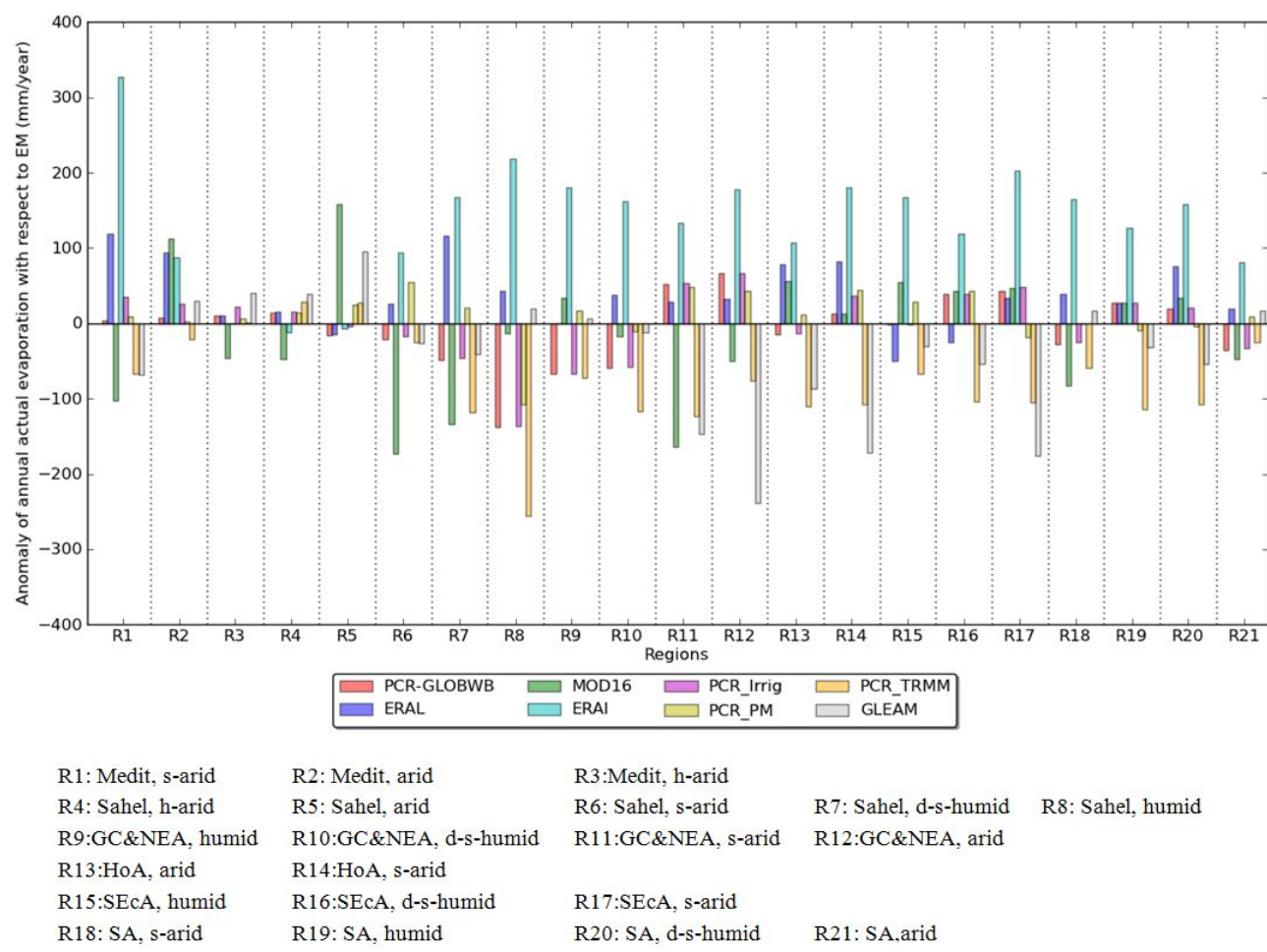

Fig. 6. Annual anomaly of evaporation for each product with respect to the evaporation multiproduct (EM) for each region.

results for a number of African river basins for the ERAI precipitation data without correction. For the scale considered in this study, it is clear that rainfall events with higher intensities result in lower evaporation values (see Figs. 6 and 7) given that PCR_TRMM evaporation is generally lower than PCR-GLOBWB evaporation. This can be explained as higher intensities lead to higher surface runoff, which keeps the water out of reach of evaporation resulting in lower evaporation rates. Moreover, for vegetated areas, less intense rainfall tends to increase the direct evaporation as the rain is more easily intercepted by the vegetation, and thus to reduce the infiltration.

The difference between the evaporation products PCR_TRMM and PCR-GLOBWB is not negligible and it varies from region to region, and therefore is important to force the hydrological model with the most suitable precipitation product for that particular region. Thiemig et al. (2012) found TRMM together with RFE to be the best satellite products available for the African continent. However, they noted that both TRMM and ERAI underestimate the amount of rainfall during the heavy rainfall events, and they explained that for the satellite products this was mainly the result of the small extent of the heavy precipitation cells, which are generally lower than the detection limit of the satellite sensors. While ERAI highly overestimates the number of rainy days, TRMM also has some overestimation of the rainy days for tropical wet and dry zones but lower than that of ERAI (Thiemig et al., 2012). Moreover, Wang et al. (2009) highlights some known "anomalies" in TRMM such as underestimation in "warm-rain" regimes. In these regimes rain is derived from non-icephase processes in clouds (see Lau and Wu, 2003 for detailed explanation).

Differences between GLEAM and the other products are partly due to the differences in input precipitation data. GLEAM is forced with PERSIANN which differs with ERAInterim and TRMM 3B42v6 across Africa (Thiemig et al., 2012). MOD16 is forced with GMAO precipitation, and biases in this compared to with ERA-Interim, TRMM, PERSIANN are also a source of the disparities between the evaporation products. The impact of the distinct precipitation inputs is difficult to quantify here as the products differ in other meteorological inputs (such as radiation) and they are based on other modelling approaches.

\section{ii. Potential evaporation data}

The potential evaporation used as a forcing appears to have some influence in the estimation of actual evaporation in some of the regions, but the difference is considerably lower than the differences between the input potential evaporation products. Already quite small differences between Hargreaves and Penman-Monteith potential evaporation resulted in appreciably smaller differences in the actual evaporation products. Moreover, large differences in the potential evaporation between MOD16 and the potential evaporation inputs 

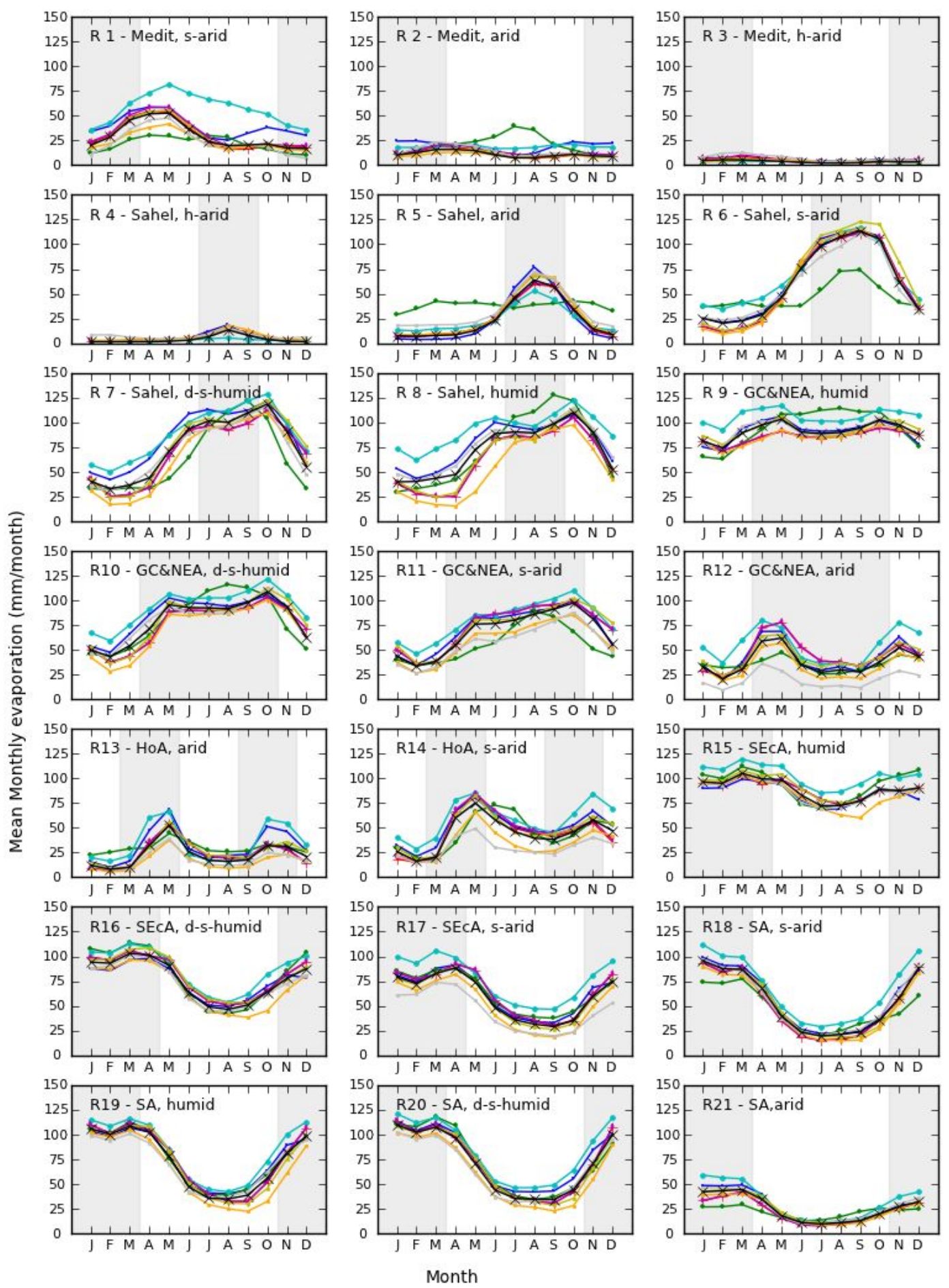

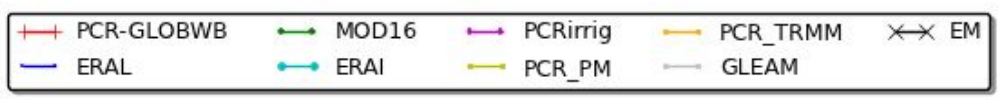

Fig. 7. Variation of mean monthly actual evaporation for each region. In grey, the wet periods, and in white the dry periods according to Sylla et al. (2010) and Jacovides et al. (2003). MOD16 product is not presented in hyper-arid areas (R3 and R4) plots due to unavailability of data for these areas. 

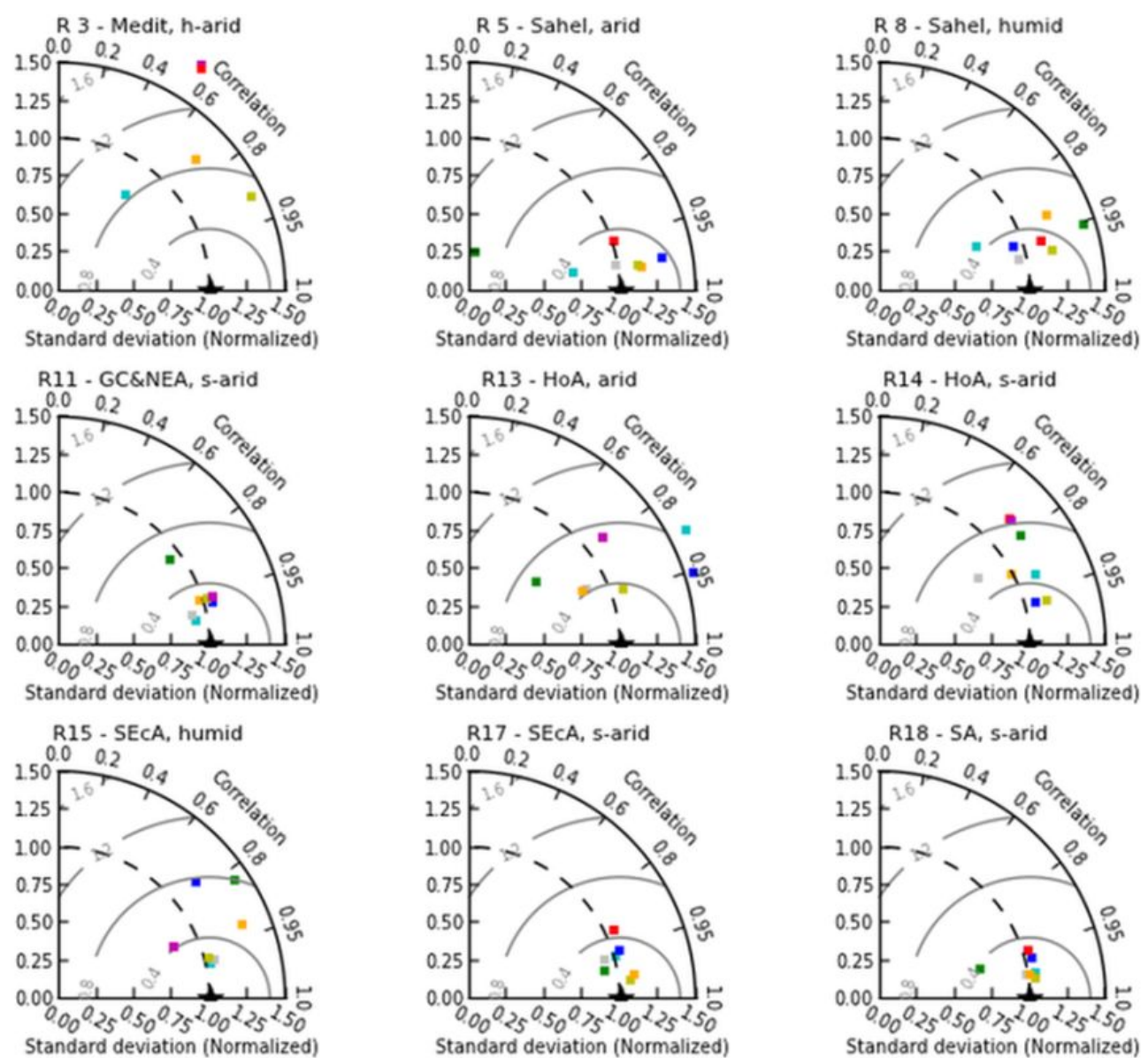

\begin{tabular}{|c|c|c|c|c|c|c|c|c|}
\hline EM & - & ERAL & " & ERAI & $=$ & PCR_PM & $=$ & GLEAM \\
\hline PCR-GLOBWB & - & MOD16 & - & PCR_Irrig & $=$ & PCR_TRMM & & \\
\hline
\end{tabular}

Fig. 8. Taylor diagrams summarizing the statistics between the monthly time series of the different products assuming the EM is the "reference".

for PCR-GLOBWB (Hargreaves and Penman-Monteith) resulted in substantially smaller differences in the actual evaporation products (see Fig. 7).

Biases in the input potential evaporation data are mainly due to differences in radiation, temperature, and vegetation data. Positive biases in the radiation from GMAO could be an important source for the higher values in the MOD16 potential evaporation compared to the other products. All the other products use the ERA-Interim net radiation or extraterrestrial radiation with the Hargreaves method. Regarding temperature inputs as stated in Sect. 3.1, we observed that differences in temperature data sets between ERAI and WorldClim might be responsible for the 20-30\% differences in the Global-PET data set from Zomer et al. (2008) and the one computed within this study.

\section{B. Effect of the model structure in the estimation of actual evaporation}

The comparison between the PCR-GLOBWB and the PCR_Irrig evaporation products can help us identify the effect of introducing an irrigation scheme in a hydrological model on simulated actual evaporation. The only difference between these two models is the introduction of the irrigation scheme in PCR_Irrig which was not included in the default PCR-GLOBWB. A recent study by van Beek et al. (2011) attributed partly the difference between PCR-GLOBWB simulated actual evaporation and ERA-40 reanalysis evaporation to the under representation of the irrigation areas in PCRGLOBWB.

It appears that introducing an irrigation scheme in the hydrological model has negligible effect in the actual evaporation results for the resolution of $0.5^{\circ} \times 0.5^{\circ}$ used in this study. Only in some regions with very large irrigation areas, marginally higher evaporation was observed. This is because 


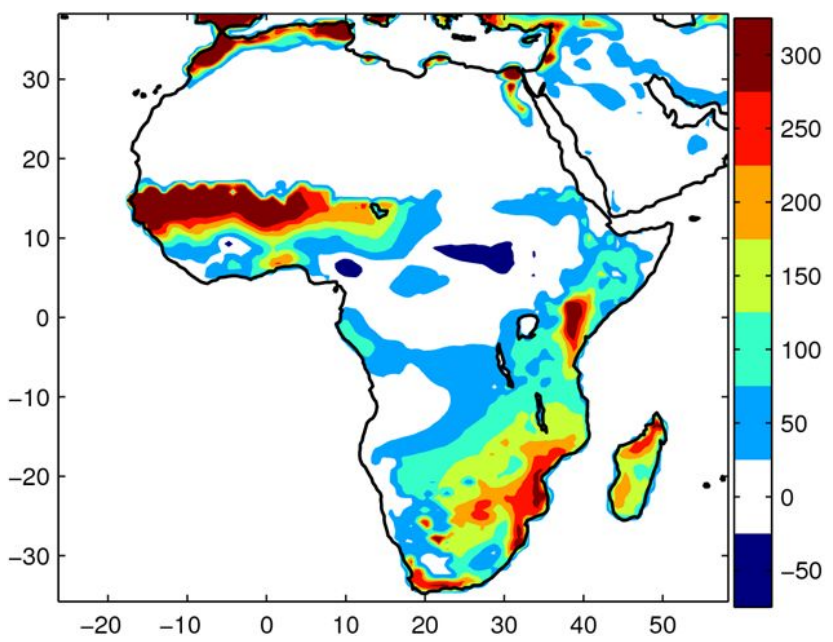

Fig. 9. Mean annual soil moisture increments (in $\mathrm{mm} \mathrm{yr}^{-1}$ ) in ERAI resulting from the soil moisture assimilation scheme.

the higher evaporations in the comparatively small irrigated areas become insignificant when averaged over large regions containing large areas without irrigation. In a cell by cell area, the difference in evaporation when irrigation is included is noticeable. Moreover, we observed considerable differences in the evaporation results when the same irrigation scheme was introduced in a finer resolution model $\left(0.05^{\circ} \times 0.05^{\circ}\right)$ for the Limpopo River basin.

Regarding ERAI and ERAL, it is interesting to notice a large impact of the differences in the two model structures on evaporation estimates. As described in Sect. 2.1.6, ERAI has an improved land-surface model, feedback with the atmosphere (through direct coupling) and soil moisture assimilation. In ERAI the effect of data assimilation is mostly to add soil moisture to the root zone, leading to increased evaporation.

Interception plays an important role in evaporation, and this may explain the generally lower values of MOD16 evaporation than the other products in (semi-)arid areas during the wet season. By analysing intra-annual variability we observed that the difference between MOD16 potential evaporation and the other products is highest during the dry season. MOD16 actual evaporation is generally higher than the EM during the dry season and lower during the wet season even though the MOD16 potential evaporation is higher in both seasons. This can be due to the representation of canopy intercepted evaporation. In MOD16, evaporation from the canopy is restricted by relative humidity, if the relative humidity is less than $70 \%$ no evaporation is considered from interception (Mu et al., 2011).

\section{Discussion and conclusions}

Possibilities to validate a continental evaporation product for Africa is still limited due to the inexistence of a continentalscale evaporation product based on ground measured data. In recent years there has been an increase in the amount of studies that focus on global evaporation estimates. Several new estimates were developed and validated with flux towers where available, mostly in North America and Europe, and received some indirect validation (e.g. comparison with another product) in other regions of the world. Moreover, some recent studies compare several of these estimates at a global scale, largely coming from land-surface models. The main contribution of this paper is to present an evaporation analysis focused on the African continent which serves as an indirect validation of methods or tools used in operational water resources assessments. Our analysis discriminates areas where there is a good consistency between different evaporation products and areas where they diverge. It also provides a range of variance in actual evaporation that can be expected in a given region, which may be useful in for example water resources management when estimating the water balance. Africa strongly relies on agriculture and several regions are often hit by severe droughts; evaporation estimates are key for assisting water managers in the estimation of water needed for irrigation. This paper compares different evaporation products for Africa and presents an Actual Evaporation Multiproduct at a $0.5^{\circ}$ resolution. This EM that integrates satellite based products, evaporation results from land-surface models and from hydrological models forced with different precipitation and potential evaporation data sets, may serve as a reference data set (benchmark).

In general ERAI and MOD16 do not show good agreement with other products in most part of Africa, while the rest of the products are more consistent. ERAL is generally quite close to the EM, and the higher values of evaporation in ERAI when compared with ERAL are partly explained by the analysis of soil moisture data assimilation in ERAI. It also appears that in some regions like in southern Africa the agreement between the products is very good, which means that use of any of these products may be equally good. In other regions, such as in humid Sahel or the Mediterranean the choice of a particular product needs to be further studied as there is a larger difference between the products. These results are in agreement with the study of Vinukollu et al. (2011) who found that the evaporation products they compared are most uncertain in tropical and subtropical monsoon regions including the Sahel.

Products compared at a monthly timescale certainly result in better outcomes than when the products are compared at a daily timescale. This study focused on the monthly and seasonal comparison, with daily comparisons considered to be beyond the scope of this study. However, monthly standard deviations of daily products differ from one product to the other and from one region to the other. A comparison of the 
monthly standard deviation of daily products (with the exception of MOD16 that did not have daily estimates) consistently showed that in arid and hyper-arid areas (R2, R3, R4, R5, R12, R13, and R21) ERAL shows the highest standard deviation, generally followed by ERAI and GLEAM. In these regions the mean values and variability of the standard deviation of PCR-GLOBWB derived products seem to be lower. In other regions, the standard deviations of all the products have roughly the same variability and mean values. Among the four PCR-GLOBWB derived products, the one forced with Penman-Monteith (PCR_PM) showed slightly higher values of standard deviation than the other three products. For every product and every region, a seasonality of the standard deviation can be observed, with the highest standard deviations during the wet seasons.

A potential action to improve this comparison study and the EM is to validate the products in different African regions with ground data, where available. Moreover, other available products could be added to the comparison and to the EM calculation to have more information on the variance between the products and a more consistent EM estimate. It is also recommended to compare the computed EM and the variability of the products with the global benchmark recently developed by Mueller et al. (2013). Similarly, in a basin-wide scale, long-term estimates of evaporation could be obtained from the water balance with an uncertainty estimate (Dingman, 1994).

\section{Appendix A}

\section{Regional analysis}

\section{A1 Mediterranean region ( $\mathrm{R} 1$ to $\mathrm{R} 3)$}

This region is characterized by higher evaporation rates in the months of March to May, after the end of the rainy season (see Fig. 7). The evaporation peak is clear in the semiarid region (R1), but becomes less noticeable in the arid region (R2) as the evaporation rates become lower and almost disappear in the hyper-arid areas (R3) where evaporation rates throughout the year are negligible. In the rainy season Fig. 7 shows a clear offset between ERAI and ERAL with respect to the other products, where the first two present considerably higher evaporation rates. In the dry season, while ERAL comes closer to the other products, the offset of ERAI is still evident. This offset of ERAI in the dry periods decreases with increasing aridity, in contrast with the MOD16 product, which shows higher evaporation rates than the remaining data sets for arid areas (R2) in the dry period. In the Mediterranean region only the dry season of the semiarid region (R1) presents quite a high variability between the different seasons for every product (see Fig. A1). In the Mediterranean region the consistency between the products decreases as aridity increases, and in hyper-arid Mediter- ranean region (R3) all the products show very little consistency (see Fig. 8).

\section{A2 Sahel (R4 to R8)}

The Sahel region is characterized by an annual evaporation cycle with one peak during the rainy season, namely from July to September (Sylla et al., 2010) (see Fig. 7). The evaporation rates become higher and the peaks become clearer with increasing humidity. Figure 7 shows that only the MOD16 product in the arid region (R5) and to a lesser extent in the semi-arid region (R6) do not capture the annual evaporation cycle, presenting a relatively uniform evaporation throughout the year. This can also be seen in Fig. 8 (R5) where the very low values of normalized standard deviation in MOD16 indicate that the amplitude of the annual cycle is underestimated. García et al. (2012) also found that MOD16 evapotranspiration product failed to capture the dynamics of evapotranspiration in the Sahelian savannah. Figure 7 shows that the lowest evaporation values are observed for PCR_TRMM during the dry season but it is not clear for the wet season. Regarding the highest evaporation values, ERAI (and secondly ERAL) present these during the dry season, but a clear behaviour cannot be observed for the wet season. The semi-arid (R6), dry sub-humid (R7) and humid Sahel (R8) are the regions that present the largest variability in the inter-annual mean cycles for each product and the higher dispersion between the products in the dry seasons. Similarly to the Mediterranean region, the hyper-arid region (R4) in the Sahel shows the least consistency between all the products. For the other sub-regions all the products have a higher consistency, (see for example Fig. 8 (R8)). Figure 8 shows that in the Sahel region ERAI product has a lower amplitude of the annual cycle than the EM, whereas PCR_PM and PCR_TRMM present a larger amplitude of the annual cycle than the EM. All the products however are well in phase (high correlation).

\section{A3 Guinean coast and north equatorial central Africa (R9 to $\mathbf{R 1 2}$ )}

This region is characterized by a bimodal precipitation cycle with unpronounced peaks and precipitation minima. This precipitation pattern results in different evaporation cycles depending on the aridity of the region (see Fig. 7). For the humid region (R9) all products show more or less uniform evaporation over the year; however, respective values between the products are different. In regions R10 and R11, the majority of the products follow roughly the same pattern, with slightly noticeable peaks around May and October. MOD16 deviates from this pattern, represents the amplitude fairly well in the annual cycle but remains out of phase (see Fig. 8). Figure 7 shows that the peaks of the evaporation cycle become more pronounced when aridity increases. The arid area (R12) has a clear bimodal evaporation cycle. For this region (R12) the GLEAM product presents the lowest values throughout the 

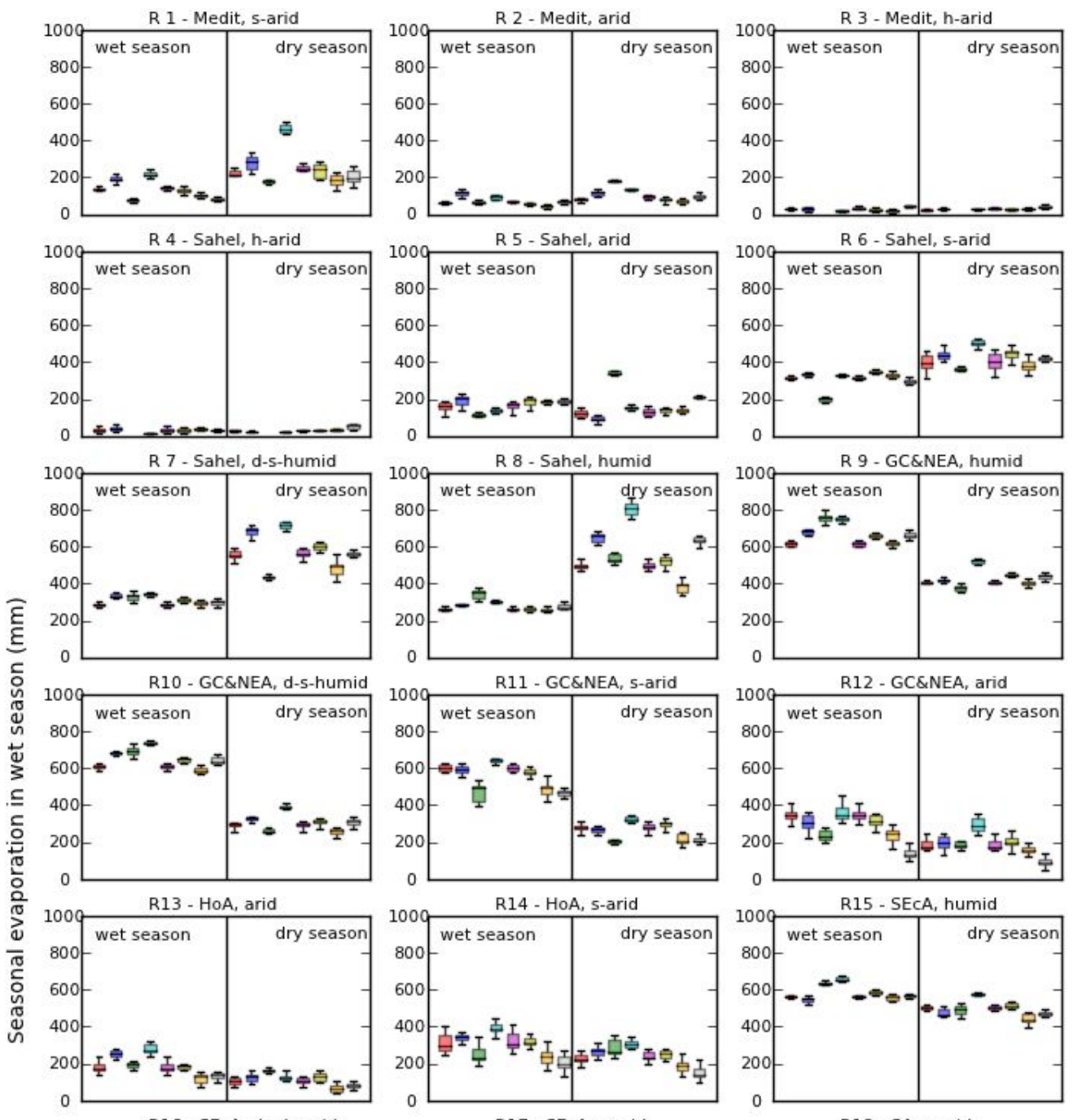

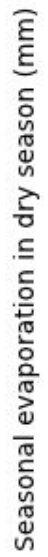
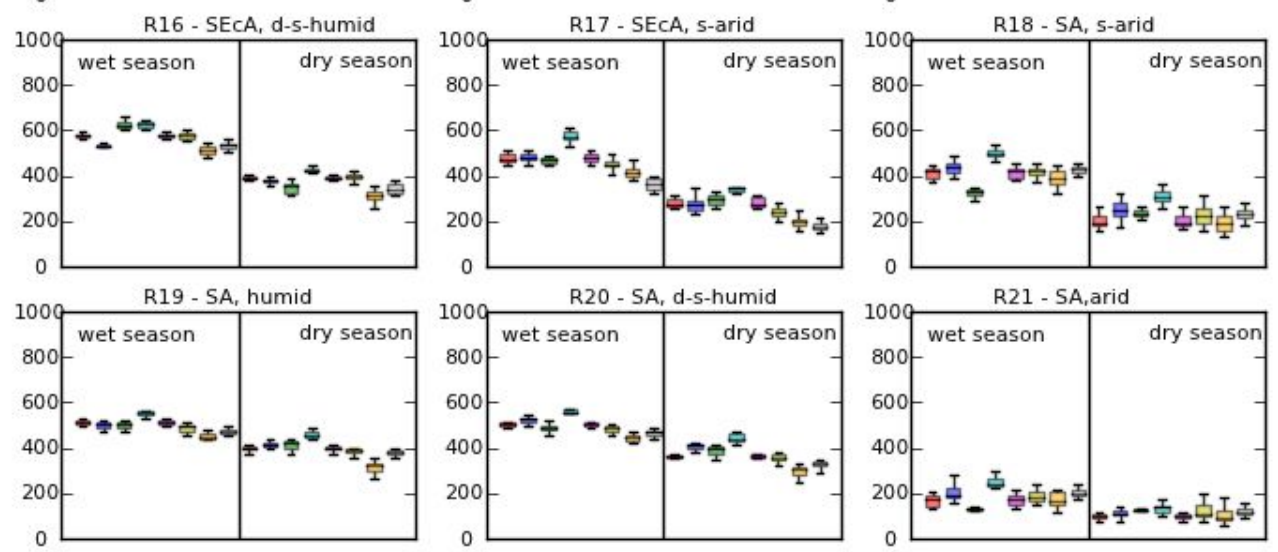

\begin{tabular}{|llll|}
$\square$ PCR-GLOBWB & MOD16 & $\square$ PCR_IrTig & $\square$ PCR_TRMM \\
ERAL & $\square$ ERAI & PCR_PM & $\square$ GLEAM \\
\hline
\end{tabular}

Fig. A1. Box plot diagrams of seasonal evaporation for each region. 
year. During the dry season ERAI present the highest values; while during the wet season a clear behaviour cannot be observed. Figure 8 suggests that most of the products have a good consistency in R11 with the exception of MOD16, while in R12 the products show less consistency.

\section{A4 Horn of Africa (R13 and R14)}

The Horn of Africa presents a bimodal evaporation cycle with defined peaks at around May and November (see Fig. 7). For this region most products show little consistency. This can be observed both in Figs. 7 and 8. In the arid Horn of Africa (R13) ERAI and ERAL present larger amplitude of the annual cycle than the EM, and MOD16 shows lower amplitude of the annual cycle than the EM. In the semi-arid region (R14), the amplitude of the annual cycle are now consistent between most products (normalized standard deviation close to one), but the correlation coefficients are rather low (the time series are not correctly phased).

\section{A5 Southern equatorial central Africa (R15 to R17)}

This region presents an evaporation seasonal cycle with a minimum in June through October and a maximum in December through April (see Fig. 7). The difference between the evaporation values in the wet and in the dry season increases with aridity. The consistency between all products seems to be quite better in the dry sub-humid region (R16) than in the humid region (R15). In R15 MOD16 and ERAL seem to be fairly out of phase (low correlation values), and PCR_TRMM presents a larger amplitude of the annual cycle than the EM. Regarding the semi-arid region (R17), the absolute amplitude of the annual cycle increases, and quite a good consistency is observed between all the products (see Fig. 8).

\section{A6 Southern Africa (R18 to R21)}

The southern Africa region show a pronounced seasonal cycle with a minimum in June through October and a maximum in December through April (see Fig. 7). In the semiarid (R18), humid (R19) and dry sub-humid (R20) regions all the products present a good consistency. In the semi-arid (R18) and arid (R21) regions MOD16 presents a lower annual cycle amplitude that the EM, which is represented in Fig. 8 (R18) by low normalized standard deviations. In the arid region (R21) all the products show less consistency.

Acknowledgements. This study was carried out as part of the DEWFORA Project (Improved Drought Early Warning and Forecasting to strengthen preparedness and adaptation to droughts in Africa) which is funded by the Seventh Framework Programme for Research and Technological Development (FP7) of the European Union (grant agreement no: 265454). Special acknowledgment goes to V. Thiemig from JRC for providing pre-processed TRMM data for the African continent and to D. Miralles from the University of Bristol for providing the global GLEAM data set. The authors would like to thank G. Balsamo for the suggestions that helped to improve the manuscript.

Edited by: M. Vanclooster

\section{References}

Allen, R. G., Pereira, L., Raes, D., and Smith, M.: Crop evapotranspiration - Guidelines for computing crop water requirements: FAO Irrigation and drainage paper No. 56, FAO, Rome, 26-40, 1998.

Alton, P., Fisher, R., Los, S., and Williams, M.: Simulations of global evapotranspiration using semiempirical and mechanistic schemes of plant hydrology, Global Biogeochem. Cy., 23, GB4023, doi:10.1029/2009GB003540, 2009.

Armstrong, R. L., Brodzik, M. J., Knowles, K., and Savoie, M.: Global monthly EASE-Grid snow water equivalent climatology, Boulder, CO: National Snow and Ice Data Center, Digital media, 2007.

Balsamo, G., Beljaars, A., Scipal, K., Viterbo, P., van den Hurk, B., Hirschi, M., and Betts, A. K.: A Revised Hydrology for the ECMWF Model: Verification from Field Site to Terrestrial Water Storage and Impact in the Integrated Forecast System, J. Hydrometeorol., 10, 623-643, 2009.

Balsamo, G., Boussetta, S., Lopez, P., and Ferranti, L.: Evaluation of ERA-Interim and ERA-Interim-GPCP-rescaled precipitation over the USA, ECMWF ERA Report Series 5, 1-25, available at: http://www.ecmwf.int/publications/library/do/references/list/ 782009, 2010.

Balsamo, G., Boussetta, S., Dutra, E., Beljaars, A., Viterbo, P., and Hurk, B.: Evolution of land-surface processes in the IFS, ECMWF Newsletter 127, Spring 2011, 2011a.

Balsamo, G., Pappenberger, F., Dutra, E., Viterbo, P., and van den Hurk, B.: A revised land hydrology in the ECMWF model: a step towards daily water flux prediction in a fully closed water cycle, Hydrol. Process., 25, 1046-1054, 2011 b.

Balsamo, G., Albergel, C., Beljaars, A., Boussetta, S., Brun, E., Cloke, H. L., Dee, D., Dutra, E., Pappenberger, F., Munoz Sabater, J., Stockdale, T., and Vitart, F.: ERA-Interim/Land: A global land-surface reanalysis based on ERA-Interim meteorological forcing, ECMWF ERA Report Series, 13, 1-25, 2012.

Belo-Pereira, M., Dutra, E., and Viterbo, P.: Evaluation of global precipitation data sets over the Iberian Peninsula, J. Geophys. Res., 116, D20101, doi:10.1029/2010JD015481, 2011.

Boussetta, S., Balsamo, G., Beljaars, A., Kral, T., and Jarlan, L.: Impact of a satellite-derived leaf area index monthly climatology in a global numerical weather prediction model, Anglais, 34, 35203542, doi:10.1080/01431161.2012.716543, 2012.

CGIAR-CSI Global Aridity and PET Database: available at: http: //www.cgiar-csi.org (last access: May 2012), 2010.

Cleugh, H. A., Leuning, R., Mu, Q., and Running, S. W.: Regional evaporation estimates from flux tower and MODIS satellite data, Remote Sens. Environ., 106, 285-304, 2007.

Dee, D. P., Uppala, S. M., Simmons, A. J., Berrisford, P., Poli, P., Kobayashi, S., Andrae, U., Balmaseda, M. A., Balsamo, G., Bauer, P., Bechtold, P., Beljaars, A. C. M., van de Berg, L., Bidlot, J., Bormann, N., Delsol, C., Dragani, R., Fuentes, M., Geer, 
A. J., Haimberger, L., Healy, S. B., Hersbach, H., Hólm, E. V., Isaksen, L., Kållberg, P., Köhler, M., Matricardi, M., McNally, A. P., Monge-Sanz, B. M., Morcrette, J. J., Park, B. K., Peubey, C., de Rosnay, P., Tavolato, C., Thépaut, J. N., and Vitart, F.: The ERA-Interim reanalysis: configuration and performance of the data assimilation system, Q. J. Roy. Meteorol. Soc., 137, 553597, doi:10.1002/qj.828, 2011.

Dingman, S. L.: Physical hydrology, Prentice Hall Englewood Cliffs, NJ, 1994.

Douville, H., Viterbo, P., Mahfouf, J. F., and Beljaars, A. C. M.: Evaluation of the Optimum interpolation and nudging techniques for soil moisture analysis using FIFE data, Mon. Weather Rev., 128, 1733-1756, 2000.

Droogers, P. and Allen, R.: Estimating Reference Evapotranspiration Under Inaccurate Data Conditions, Irriga. Drain. Syst., 16, 33-45, 2002.

Droogers, P., Immerzeel, W. W., Terink, W., Hoogeveen, J., Bierkens, M. F. P., van Beek, L. P. H., and Debele, B.: Water resources trends in Middle East and North Africa towards 2050, Hydrol. Earth Syst. Sci., 16, 3101-3114, doi:10.5194/hess-163101-2012, 2012.

Drusch, M., Scipal, K., de Rosnay, P., Balsamo, G., Andersson, E., Bougeault, P., and Viterbo, P.: Exploitation of satellite data in the surface analysis. ECMWF Tech. Memo. No. 576, available at: http://www.ecmwf.int/publications/library/do/ references/show?id=88712, 2008.

EUMETSAT: The EUMETSAT Satellite Application Facility on Land Surface Analysis (LSA SAF) - Product User Manual, Evapotranspiration (ET), 2011.

FAO: Irrigation Potential in Africa: A Basin Approach, FAO-UN, Rome, 1997.

García, M., Sandholt, I., Ceccato, P., Mougin, E., Kergoat, L., and Timouk, F.: Estimating evaportranspiration in the Sahel using remote sensing products 30th AMS Conference on Agricultural and Forest Meteorology, Boston, USA, 2012.

Ghilain, N., Arboleda, A., and Gellens-Meulenberghs, F.: Evapotranspiration modelling at large scale using near-real time MSG SEVIRI derived data, Hydrol. Earth Syst. Sci., 15, 771-786, 10, http://www.hydrol-earth-syst-sci.net/15/771/10/.5194/hess-15771-2011, 2011.

Hagemann, S., Botzet, M., Dümenil, L., and Machenhauer, B.: Derivation of global GCM boundary conditions from $1 \mathrm{~km}$ land use satellite data, Max-Planck-Institut für Meteorologie, 1999.

Hargreaves, G. H. and Allen, R. G.: History and Evaluation of Hargreaves Evapotranspiration Equation, J. Irrig. Drain. Eng., 129, 53-63, 2003.

Hijmans, R. J., Cameron, S. E., Parra, J. L., Jones, P. G., and Jarvis, A.: Very high resolution interpolated climate surfaces for global land areas, Int. J. Climatol., 25, 1965-1978, 2005.

Huffman, G. J., Adler, R. F., Bolvin, D. T., and Gu, G.: Improving the global precipitation record: GPCP version 2.1, Geophys. Res. Lett, 36, L17808, doi:10.1029/2009GL040000, 2009.

Jacovides, C. P., Tymvios, F. S., Asimakopoulos, D. N., Theofilou, K. M., and Pashiardes, S.: Global photosynthetically active radiation and its relationship with global solar radiation in the Eastern Mediterranean basin, Theor. Appl. Climatol., 74, 227-233, 2003.

Jiménez, C., Prigent, C., Mueller, B., Seneviratne, S. I., McCabe, M. F., Wood, E. F., Rossow, W. B., Balsamo, G., Betts, A. K., Dirmeyer, P. A., Fisher, J. B., Jung, M., Kanamitsu, M.,
Reichle, R. H., Reichstein, M., Rodell, M., Sheffield, J., Tu, K., and Wang, K.: Global intercomparison of 12 land surface heat flux estimates, J. Geophys. Res.-Atmos., 116, D02102, 10.1029/2010jd014545, 2011.

Keys, R.: Cubic convolution interpolation for digital image processing, Acoustics, Speech and Signal Processing, IEEE Trans., 29, 1153-1160, 1981.

Kim, H. W., Hwang, K., Mu, Q., Lee, S. O., and Choi, M.: Validation of MODIS 16 global terrestrial evapotranspiration products in various climates and land cover types in Asia, KSCE J. Civil Eng., 16, 229-238, 2012.

Kingston, D. G., Todd, M. C., Taylor, R. G., Thompson, J. R., and Arnell, N. W.: Uncertainty in the estimation of potential evapotranspiration under climate change, Geophys. Res. Lett., 36, L20403, doi:10.1029/2009GL040267, 2009.

Lau, K. M. and $\mathrm{Wu}, \mathrm{H}$. T.: Warm rain processes over tropical oceans and climate implications, Geophys. Res. Lett., 30, 2290 , doi:10.1029/2003GL018567, 2003.

Liu, Y., Yamaguchi, Y., and Ke, C.: Reducing the discrepancy between ASTER and MODIS land surface temperature products, Sensors, 7, 3043-3057, 2007.

McClain, M.: Balancing Water Resources Development and Environmental Sustainability in Africa: A Review of Recent Research Findings and Applications, Ambio, 42, 549-565, doi:10.1007/s13280-012-0359-1, 2012.

Miralles, D. G., Gash, J. H., Holmes, T. R. H., de Jeu, R. A. M., and Dolman, A. J.: Global canopy interception from satellite observations, J. Geophys. Res.-Atmos., 115, D16122, doi:10.1029/2009jd013530, 2010.

Miralles, D. G., De Jeu, R. A. M., Gash, J. H., Holmes, T. R. H., and Dolman, A. J.: Magnitude and variability of land evaporation and its components at the global scale, Hydrol. Earth Syst. Sci., 15, 967-981, doi:10.5194/hess-15-967-2011, 2011a.

Miralles, D. G., Holmes, T. R. H., De Jeu, R. A. M., Gash, J. H., Meesters, A. G. C. A., and Dolman, A. J.: Global land-surface evaporation estimated from satellite-based observations, Hydrol. Earth Syst. Sci., 15, 453-469, doi:10.5194/hess-15-453-2011, $2011 b$.

Miralles, D. G., van den Berg, M. J., Gash, J. H., Parinussa, R. M., de Jeu, R. A. M., Beck, H. E., Holmes, T. R. H., Jiménez, C., Verhoest, N. E. C., Dorigo, W. A., Teuling, A. J., and Johannes Dolman, A.: El Niño-La Niña cycle and recent trends in continental evaporation, Nat. Clim. Change, doi:10.1038/nclimate2068, in press, 2013.

Mu, Q., Heinsch, F. A., Zhao, M., and Running, S. W.: Development of a global evapotranspiration algorithm based on MODIS and global meteorology data, Remote Sens. Environ., 111, 519-536, 2007.

Mu, Q., Zhao, M., and Running, S. W.: Improvements to a MODIS global terrestrial evapotranspiration algorithm, Remote Sens. Environ., 115, 1781-1800, 2011.

Mueller, B., Seneviratne, S. I., Jimenez, C., Corti, T., Hirschi, M., Balsamo, G., Ciais, P., Dirmeyer, P., Fisher, J. B., Guo, Z., Jung, M., Maignan, F., McCabe, M. F., Reichle, R., Reichstein, M., Rodell, M., Sheffield, J., Teuling, A. J., Wang, K., Wood, E. F., and Zhang, Y.: Evaluation of global observations-based evapotranspiration datasets and IPCC AR4 simulations, Geophys. Res. Lett., 38, L06402, doi:10.1029/2010g1046230, 2011. 
Mueller, B., Hirschi, M., Jimenez, C., Ciais, P., Dirmeyer, P. A., Dolman, A. J., Fisher, J. B., Jung, M., Ludwig, F., Maignan, F., Miralles, D., McCabe, M. F., Reichstein, M., Sheffield, J., Wang, K. C., Wood, E. F., Zhang, Y., and Seneviratne, S. I.: Benchmark products for land evapotranspiration: LandFlux-EVAL multidataset synthesis, Hydrol. Earth Syst. Sci. , 17, 3707-3720, doi:10.5194/hess-17-3707-2013, 2013.

Overgaard, J., Rosbjerg, D., and Butts, M. B.: Land-surface modelling in hydrological perspective - a review, Biogeosciences, 3, 229-241, doi:10.5194/bg-3-229-2006, 2006.

Owe, M., de Jeu, R., and Holmes, T.: Multisensor historical climatology of satellite-derived global land surface moisture, J. Geophys. Res. Earth Surf., 113, F01002, doi:10.1029/2007JF000769, 2008.

Portmann, F., Siebert, S., Bauer, C., and Döll, P.: Global data set 895 of monthly growing areas of 26 irrigated crops, Frankfurt Hydrology Paper 06, Institute of Physical Geography, University of Frankfurt, Frankfurt am Main, Germany, 2008.

Portmann, F. T., Siebert, S., and Döll, P.: MIRCA2000 - Global monthly irrigated and rainfed crop areas around the year 2000: A new high-resolution data set for agricultural and hydrological modeling, Global Biogeochem. Cy., 24, GB1011, doi:10.1029/2008GB003435, 2010.

Rossow, W. B. and Schiffer, R. A.: Advances in Understanding Clouds from ISCCP, B. Am. Meteorol. Soc., 80, 2261-2287, 1999.

Siebert, S., Döll, P., Feick, S., Hoogeveen, J., and Frenken, K.: Global Map of Irrigation Areas version 4.0.1, edited by: Johann Wolfgang Goethe University, Frankfurt am Main, Germany/Food and Agriculture Organization of the United Nations, Rome, Italy, 2007.

Sperna Weiland, F. C., van Beek, L. P. H., Kwadijk, J. C. J., and Bierkens, M. F. P.: On the Suitability of GCM Runoff Fields for River Discharge Modeling: A Case Study Using Model Output from HadGEM2 and ECHAM5, J. Hydrometeorol., 13, 140-154, doi:10.1175/jhm-d-10-05011.1, 2011.

Sperna Weiland, F. C., Tisseuil, C., Dürr, H. H., Vrac, M., and van Beek, L. P. H.: Selecting the optimal method to calculate daily global reference potential evaporation from CFSR reanalysis data for application in a hydrological model study, Hydrol. Earth Syst. Sci., 16, 983-1000, doi:10.5194/hess-16-983-2012, 2012.

Sylla, M. B., Coppola, E., Mariotti, L., Giorgi, F., Ruti, P., Dell'Aquila, A., and Bi, X.: Multiyear simulation of the African climate using a regional climate model (RegCM3) with the high resolution ERA-interim reanalysis, Clim. Dynam., 35, 231-247, 2010.

Szczypta, C., Calvet, J.-C., Albergel, C., Balsamo, G., Boussetta, S., Carrer, D., Lafont, S., and Meurey, C.: Verification of the new ECMWF ERA-Interim reanalysis over France, Hydrol. Earth Syst. Sci., 15, 647-666, doi:10.5194/hess-15-647-2011, 2011.

Teuling, A., Hirschi, M., Ohmura, A., Wild, M., Reichstein, M., Ciais, P., Buchmann, N., Ammann, C., Montagnani, L., and Richardson, A.: A regional perspective on trends in continental evaporation, Geophys. Res. Lett, 36, L02404, doi:10.1029/2008GL036584, 2009.

Thiemig, V., Rojas, R., Zambrano-Bigiarini, M., Levizzani, V., and De Roo, A.: Validation of Satellite-Based Precipitation Products
Over Sparsely-Gauged African River Basins, J. Hydrometeorol., 13, 1760-1783, doi:10.1175/JHM-D-12-032.1, 2012.

UNEP: World atlas of desertification 2ED, UNEP (United Nations Environment Programme) London, 1997.

USGS: MODIS Overview - Retrieved on April 2012, available at: https://lpdaac.usgs.gov/products/modis_overview (last access: April 2012), 2012.

van Beek, L. P. H. and Bierkens, M. F. P.: The Global Hydrological Model PCR-GLOBWB: Conceptualization, Parameterization and Verification, Utrecht University, Faculty of Earth Sciences, Department of Physical Geography, Utrecht, tThe Netherlands, 2009.

van Beek, L. P. H., Wada, Y., and Bierkens, M. F. P.: Global monthly water stress: 1 . Water balance and water availability, Water Resour. Res., 47, W07517, doi:10.1029/2010WR009791, 2011.

Van den Hurk, B., Viterbo, P., Beljaars, A. C. M., and Betts, A. K.: Offline validation of the ERA40 surface scheme, ECMWF Tech. Memo. 295, 1-42, 2000.

van der Ent, R. J., Savenije, H. H. G., Schaefli, B., and Steele-Dunne, S. C.: Origin and fate of atmospheric moisture over continents, Water Resour. Res., 46, W09525, doi:10.1029/2010WR009127, 2010.

Vinukollu, R. K., Meynadier, R., Sheffield, J., and Wood, E. F.: Multi-model, multi-sensor estimates of global evapotranspiration: climatology, uncertainties and trends, Hydrol. Process., 25, 3993-4010, doi:10.1002/hyp.8393, 2011.

Wada, Y., van Beek, L. P. H., Viviroli, D., Dürr, H. H., Weingartner, R., and Bierkens, M. F. P.: Global monthly water stress: 2. Water demand and severity of water stress, Water Resour. Res., 47, W07518, doi:10.1029/2010wr009792, 2011.

Wang, N.-Y., Liu, C., Ferraro, R., Wolff, D., Zipser, E., and Kummerow, C.: TRMM 2A12 Land Precipitation Product - Status and Future Plans, J. Meteorol. Soc. Jpn. Ser. II, 87A, 237-253, 2009.

Wang, T. and Zlotnik, V. A.: A complementary relationship between actual and potential evapotranspiration and soil effects, J. Hydrol., 456-457, 146-150, doi:10.1016/j.jhydrol.2012.03.034, 2012.

Weiß, M. and Menzel, L.: A global comparison of four potential evapotranspiration equations and their relevance to stream flow modelling in semi-arid environments, Adv. Geosci., 18, 15-23, doi:10.5194/adgeo-18-15-2008, 2008.

Zhang, K., Kimball, J. S., Nemani, R. R., and Running, S. W.: A continuous satellite-derived global record of land surface evapotranspiration from 1983 to 2006, Water Resour. Res, 46, W09522, doi:10.1029/2009WR008800, 2010.

Zhao, M., Running, S. W., and Nemani, R. R.: Sensitivity of Moderate Resolution Imaging Spectroradiometer (MODIS) terrestrial primary production to the accuracy of meteorological reanalyses, J. Geophys. Res., 111, G01002, doi:10.1029/2004jg000004, 2006.

Zomer, R. J., Trabucco, A., Bossio, D. A., van Straaten, O., and Verchot, L. V.: Climate Change Mitigation: A Spatial Analysis of Global Land Suitability for Clean Development Mechanism Afforestation and Reforestation, Agric. Ecosystems and Envir., 126, 67-80, 2008. 